\title{
The beauty of being (label)-free: sample preparation methods for SWATH-MS and next-generation targeted proteomics
}

\section{[version 1; peer review: 2 approved]}

\author{
Jakob Vowinckel*, Floriana Capuano*, Kate Campbell, Michael J. Deery, \\ Kathryn S. Lilley, Markus Ralser
}

Cambridge Systems Biology Centre and Dept. of Biochemistry, University of Cambridge, Cambridge, CB2 1GA, UK

${ }^{*}$ Equal contributors

V1 First published: 13 Dec 2013, 2:272
https://doi.org/10.12688/f1000research.2-272.v1

Latest published: $07 \mathrm{Apr} 2014,2: 272$

https://doi.org/10.12688/f1000research.2-272.v2

\begin{abstract}
The combination of qualitative analysis with label-free quantification has greatly facilitated the throughput and flexibility of novel proteomic techniques. However, such methods rely heavily on robust and reproducible sample preparation procedures. Here, we benchmark a selection of in gel, on filter, and in solution digestion workflows for their application in label-free proteomics. Each procedure was associated with differing advantages and disadvantages. The in gel methods interrogated were cost effective, but were limited in throughput and digest efficiency. Filter-aided sample preparations facilitated reasonable processing times and yielded a balanced representation of membrane proteins, but led to a high signal variation in quantification experiments. Two in solution digest protocols, however, gave optimal performance for label-free proteomics. A protocol based on the detergent RapiGest led to the highest number of detected proteins at second-best signal stability, while a protocol based on acetonitrile-digestion, RapidACN, scored best in throughput and signal stability but came second in protein identification. In addition, we compared label-free data dependent (DDA) and data independent (SWATH) acquisition. While largely similar in protein detection, SWATH outperformed DDA in quantification, reducing signal variation and markedly increasing the number of precisely quantified peptides.
\end{abstract}

\section{Keywords}

label-free quantitative proteomics, in gel digest, filter-aided sample preparation, RapiGest, acetonitrile-based protein digestion, SWATH, data dependent acquisition

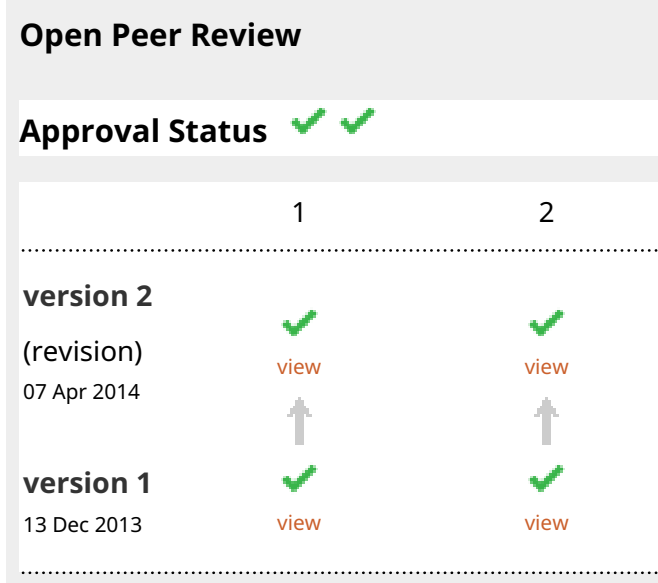

1. Xianyin Lai, Indiana University, Indianapolis, IN, USA

2. Nick Morrice, The Beatson Institute for Cancer Research, Glasgow, UK

Any reports and responses or comments on the article can be found at the end of the article. 
Corresponding author: Markus Ralser (mr559@cam.ac.uk)

Competing interests: The authors declare no competing interests.

Grant information: This work was funded by the Isaac Newton Trust, the Wellcome Trust (RG 093735/Z/10/Z) to MR, the ERC (Starting grant 260809) to MR and the 7th Framework Programme of the European Union (262067- PRIME-XS) to KSL. M.R. is a Wellcome Trust Research Career Development and Wellcome-Beit prize fellow.

The funders had no role in study design, data collection and analysis, decision to publish, or preparation of the manuscript.

Copyright: ๑ 2013 Vowinckel J et al. This is an open access article distributed under the terms of the Creative Commons Attribution License, which permits unrestricted use, distribution, and reproduction in any medium, provided the original work is properly cited. Data associated with the article are available under the terms of the Creative Commons Zero "No rights reserved" data waiver (CC0 1.0 Public domain dedication).

How to cite this article: Vowinckel J, Capuano F, Campbell $\mathrm{K}$ et al. The beauty of being (label)-free: sample preparation methods for SWATH-MS and next-generation targeted proteomics [version 1; peer review: 2 approved] F1000Research 2013, 2:272

https://doi.org/10.12688/f1000research.2-272.v1

First published: 13 Dec 2013, 2:272 https://doi.org/10.12688/f1000research.2-272.v1 


\section{Introduction}

Mass spectrometry (MS)-based proteomics facilitates the identification of a large number of proteins in a single experiment ${ }^{1-3}$. As a result this technique has been established as a powerful complement to the classic tools of protein chemistry, such as westernblotting or enzyme-linked immunosorbent (ELISA) assays, which are of considerably lower throughput and specificity. Where initial proteomic workflows mainly aimed to identify proteins, quantification has become a major focus of much of technology development in recent years ${ }^{4,5}$. On a quantitative liquid chromatography/mass spectrometry (LC-MS) platform the amount of analyte and the corresponding chromatographic peak area are in linear correlation, hence concentration values are obtained through comparison with reference standards ${ }^{6}$. A technically powerful approach for protein quantification involves the use of isotope-labelled standards that show a similar structure and chromatographic behaviour to the target molecule, but are distinguished from the target by mass ${ }^{7}$. When added at an early stage of the quantification workflow, they allow for correction of analyte loss during sample preparation and analysis, hence rendering the quantification experiment robust. However, the requirement for isotope-labelled standards makes proteomics workflows expensive and reduces flexibility, as their production is laborious and applicable only to samples for which these standards can be obtained or generated (please see the Discussion). Moreover, as both the analyte and standard need to be measured, they double the analyte load for the mass spectrometer. Consequently, recent developments that have enabled label-free peptide and protein quantification have attracted much attention ${ }^{8-12}$. In a label-free experiment, quantification is achieved through comparison of peak areas obtained for an analyte under two or more biological conditions; for instance to compare a wild-type versus a mutant, a compoundexposed versus a control condition, or a biological time series ${ }^{13-16}$. Upon normalisation, ideally to one or more unaffected internal standards, this approach yields a relative expression value for the target protein. This measure is then used to evaluate whether the expression of the target is altered between the conditions tested. In the case of high sequence coverage, absolute quantities may also be estimated, as peak intensities obtained for the best ionizing peptides correlate in approximation with their absolute concentration ${ }^{10,12}$.

The absence of an internal standard spiked early in sample preparation protocols means that label-free methods are sensitive to technical variance, and consequently, label-free proteomics requires high instrument performance and standardization of sample preparation methods. In terms of instrumentation, limitations arise from the linear range of the mass spectrometer and the sample capacity of the liquid chromatography. Moreover, in untargeted proteomics, the stochastic nature of data-dependent acquisition methods, where ions are selected for analysis based on their intensity, reduces the number of quantifiable peptides to only those fragmented in all samples ${ }^{17,18}$. This problem is a consequence of the high numbers of co-eluting peptides that may considerably exceed the mass spectrometer's sampling speed when analysing full proteomes, a situation that is amplified by the high number of replicates used in a label-free study. By facilitating data-independent acquisition, where all ions are fragmented irrespective of their intensity, recent studies have demonstrated the possibility of circumventing the need of isolating individual peptides ${ }^{11,17}$. One such method, pioneered by the Waters Corporation, is termed MS ${ }^{\mathrm{E}, 11}$. In this approach fragment ions are assumed to have the same elution profiles as their precursors; this similarity is then used to pair fragments and precursors when a number of parent ions are co-fragmented. Fragment pairs and their corresponding precursor ions are typically retrospectively paired prior to database searching ${ }^{11}$. More recently, in a workflow termed SWATH, a mass range relevant for peptide-based proteomics $(400-1200 \mathrm{~m} / \mathrm{z})$ is scanned in $25 \mathrm{~m} / \mathrm{z}$ windows, in which all ions that fall into that window are simultaneously fragmented (MS/MS $\left.{ }^{\text {all }}\right)$. Quantification is then conducted based on the peak areas of extracted ion chromatograms (XIC), which are computationally reconstituted from the merged spectra on the basis of both experimental and in silico generated spectral information ${ }^{17}$.

Sample preparation techniques are equally important for the performance of a label-free experiment, and easier to optimize on a daily basis than the mass spectrometer's properties. The main objective for a label-free sample preparation method is to obtain stable peak intensities between replicate sample preparations. Consequently, the ideal workflow avoids processing steps that are prone to stochastic analyte losses, and the LC-MS set up is operated in a way that ensures the dynamic range of the instrument is not exhausted. These objectives may differ to classic shotgun proteomics, where the number of identifiable peptides and proteins is the most important value, and a higher variation in signal intensities is acceptable. Hence, a sample preparation method and LC-MS/MS configuration, which is ideal for identifying a maximum of proteins, may be sub-optimal for label-free quantification, and vice versa. For instance, pre-fractionation of the sample prior to the LC-MS/MS analysis, a popular strategy to improve peptide identification, adds another level of complexity to the sample preparation increasing the signal variability and thus, is avoided wherever possible.

The main objective of the study presented here is to benchmark proteomic sample preparation methods for their suitability in labelfree proteomic studies. We compare popular sample protocols that are based on in gel $^{19}$, filter-aided ${ }^{20,21}$ and in solution ${ }^{9,22}$ digestion procedures. Processing identical proteome samples obtained from budding yeast, and acquiring proteomic data without further prefractionation on two LC-MS/MS platforms, these methods are compared by their performance in sample preparation, their precision in label-free quantification experiments and their effectiveness in terms of time and reagents. Through the analysis of these samples on a $5600 \mathrm{QqTOF}^{23}$ instrument operating in either a datadependent mode or $\mathrm{SWATH}^{24}$ mode, this study concludes with an evaluation of data-dependent and data independent acquisition, and suggestions about the optimal protocol selection.

\section{Experimental section}

\section{Reagents}

For sample preparation the following reagents were used: Water ULC-MS grade (Greyhound Cat. No. 23214125), formic acid 99\% ULC-MS (Greyhound Cat. No. BIO-06914131) and acetonitrile ULC-MS grade (Greyhound Cat. No. Bio-012041-2.5L). Chemicals were obtained from Sigma, with the exception of RapiGest (Waters, Cat. No. 186001861), trypsin (Promega Cat. No. V5111), LysC (Promega, Cat. No. No. V1071), complete EDTA-free protease inhibitor cocktail tablets (used in the eFASP protocol) (Roche 
Cat. No. 11873580001), dithiothreitol (Melford Cat No. MB1015), ammonium bicarbonate (Fluka Cat. No. 40867-50G-F), sodium dodecyl sulfate(SDS, Melford Cat. No. S1030), 30\% acrylamide/ $0.8 \%$ bis-acrylamide (Protogel, Geneflow Limited Cat. No. EC-890), trin-butylphosphate (Fluka Cat. No. 90820-100ML) and BCA Protein assay kit (Pierce Cat. No. 23225).

\section{Preparation of yeast cells}

All experiments were conducted using a single culture derived from a single colony of the yeast strain BY $4741^{25}$. The strain was transferred to yeast peptone dextrose (YPD) media prepared as described $\mathrm{in}^{26}$ and incubated at $30^{\circ} \mathrm{C}$ at $200 \mathrm{rpm}$ overnight (ON). Subsequently the $\mathrm{ON}$ culture was diluted to an optical density $\left(\mathrm{OD}_{600}\right)$ of 0.2 as measured on an Ultropsec 2000 (Amersham) spectrophotometer, and incubated at $30^{\circ} \mathrm{C}$ until reaching $\mathrm{OD}_{600}=2$. The culture was split into aliquots corresponding to $10 \mathrm{OD}_{600}$ units, and stored at $-80^{\circ} \mathrm{C}$ until processing.

Protein sample preparation for DDA and SWATH analysis A detailed protocol for each of the six procedures is available in the Supplementary Materials (found at the end of the document in the offline version) (see Supplementary protocol 1Supplementary protocol 6). In brief, protein samples were prepared from $30 \mathrm{mg}$ (wet weight) of yeast pellet. For the in gel digest protocols, protein extraction was performed either in $200 \mu$ l SDT buffer (4\% SDS, $100 \mathrm{mM}$ Tris/HCl pH 7.6, 0.1 M dithiothreitol) or $0.05 \mathrm{M}$ ammonium bicarbonate using a Fast-Prep 24 instrument (MP Biomedicals). Fifty $\mu \mathrm{g}$ of protein was applied onto a denaturing polyacrylamide gel and subjected to electrophoresis (for details please see Supplementary protocol 1 and Supplementary protocol 2). The sample was excised as single band, cut in pieces, and subjected to tryptic digestion ${ }^{27}$. For the filter-aided protocols (FASP, Supplementary protocol 3 and Supplementary protocol 4) protein extraction was performed either in $200 \mu \mathrm{l}$ SDT buffer (4\% SDS, $100 \mathrm{mM}$ Tris/HCl pH 7.6, 0.1 M dithiothreitol) (FASP, Supplementary protocol 3) or lysis buffer (1\% SDS, $10 \mathrm{mM}$ Tris/HCl pH 7.4, 0.15 M $\mathrm{NaCl}, 1 \mathrm{mM}$ EDTA in PBS) (eFASP, Supplementary protocol 4). For both protocols the digestion was performed directly on filters (Amicon Ultra-0.5 Centrifugal Filter Unit with Ultracel-3 membrane, Millipore). The FASP procedure (Supplementary protocol 3) involved a treatment with endoproteinase Lys-C (Promega) prior to digestion with trypsin ${ }^{20}$, while the eFASP Supplementary protocol 4) required protein precipitation using tri-n-butylphosphate/acetone/methanol mix (1:12:1) for lipid removal before digestion $^{21}$. For in solution digest protocols Supplementary protocol 5 and Supplementary protocol 6) protein extraction was performed either in $200 \mu \mathrm{l}$ lysis buffer (0.1 M NaOH, $0.05 \mathrm{M}$ EDTA, 2\% SDS, $2 \% \beta$-mercaptoethanol) (RapiGest) or $0.05 \mathrm{M}$ ammonium bicarbonate $(\text { RapidACN })^{20}$ or using glass-bead lyses using the Fast-Prep 24 instrument (MP Biomedicals), respectively. The in solution digest protocol based on the detergent RapiGest method included a step of protein precipitation for lipid removal through centrifugation prior to trypsin treatment. For the in solution acetonitrile-based digestion protocol, a clean-up step using $3 \mathrm{kDa}$ molecular cut off filters (Amicon Ultra-0.5 Centrifugal Filter Unit with Ultracel-3 membrane, Millipore) was performed immediately after trypsin digestion ${ }^{9}$. In order to maximize the proteome depth for the generation of a SWATH ion library, tryptic digests prepared with the RapidACN protocol were separated by high $\mathrm{pH}$ reverse phase chromatography before LC-MS/MS analysis. A reverse phase column (Waters, BEH C18, $2.1 \times 150 \mathrm{~mm}, 1.7 \mu \mathrm{m}$ ) was utilised in combination with a $20 \mathrm{mM}$ ammonium formate to $20 \mathrm{mM}$ ammonium formate/80\% ACN gradient. Twenty fractions were collected and supplemented with HRM standard peptide kit (Biognosys) prior to analysis.

\section{LC-MS/MS analysis}

LC-MS/MS analysis of digested S. cerevisiae lysates was performed on a Tandem Quadrupole Time-of-Flight mass spectrometer (AB/Sciex TripleTOF5600) coupled to a Nanospray III Ion Source (AB/Sciex) and nano-HPLC (Eksigent Ultra 2D) (referred as TripleTOF platform), or hybrid quadrupole orbitrap mass spectrometer (QExactive, Thermo Scientific) coupled to a Dionex Ultimate 3000 and an Easy-spray nanospray ion source (referred as QExactive platform).

On the TripleTOF platform, peptide separation was carried out by first removing impurities on a pre-column (C18 PepMap100 column NAN75-15-03-C18-PM, Thermo Fisher Scientific Cat. No. 160321 ) running isocratically at $100 \%$ solvent $A$ at a flow rate of $5 \mu \mathrm{L} \mathrm{min}{ }^{-1}$ for $6 \mathrm{~min}$. Peptides were then eluted onto the analytical column (Zorbax 300SB-C18 column, $75 \mu \mathrm{m}$ id $\times 15 \mathrm{~cm} 3.5 \mu \mathrm{m}$, Agilent Technologies Cat. No. 5065-9911), and separated on a linear gradient of 5-35\% solvent B for $155 \mathrm{~min}$ at a flow rate of $300 \mathrm{~nL}$ $\mathrm{min}^{-1}$. Peptides were injected into the mass spectrometer using $10 \mu \mathrm{m}$ SilicaTip electrospray emitters (New Objective Cat. No. FS36020-10-N-20-C12), and operating the ion source with the following parameters: $\mathrm{ISVF}=2500 ; \mathrm{GS} 1=12 ; \mathrm{CUR}=25$. The data acquisition mode in the DDA experiments was set to obtain a high resolution TOF-MS scan over a mass range 400-1250 m/z, followed by MS/MS scans of 20 ion candidates per cycle with dynamic background subtraction, operating the instrument in high sensitivity mode. The selection criteria for the parent ions included the intensity, where ions had to be greater than $150 \mathrm{cps}$, with a charge state between 2 and 4. The dynamic exclusion duration was set for $15 \mathrm{~s}$. Collisioninduced dissociation was triggered by rolling collision energy (Supplementary Table 1). The ion accumulation time was set to $250 \mathrm{~ms}$ (MS) and to $100 \mathrm{~ms}$ (MS/MS). For SWATH MS-based experiments the instrument was tuned to specifically allow a quadrupole resolution of $25 \mathrm{Da} /$ mass selection. An isolation width of $25 \mathrm{Da}$ was set in a looped mode over the full mass range $(400-1250 \mathrm{~m} / \mathrm{z})$ scan and 32 overlapping windows were constructed ${ }^{28}$. An accumulation time of $100 \mathrm{~ms}$ was set for each fragment ion resulting in a total ion cycle of $3.3 \mathrm{~s}$.

For LC-MS/MS analysis using the QExactive platform, separation of peptides was performed at a flow rate of $300 \mathrm{~nL} \mathrm{~min}^{-1}$ using a reverse-phase nano column (Easy-spray, Thermo Scientific PepMap C18, $2 \mu \mathrm{m}$ particle size, $100 \AA$ pore size, $75 \mu \mathrm{m}$ i.d. $\times 50 \mathrm{~cm}$ length). Peptides were loaded onto a pre-column (Thermo Scientific PepMap $100 \mathrm{C} 18,5 \mu \mathrm{m}$ particle size, $100 \AA$ pore size, $300 \mu \mathrm{m}$ i.d. $\times 5 \mathrm{~mm}$ length) from the Ultimate 3000 autosampler (Dionex) with $0.1 \%$ formic acid for 3 minutes at a flow rate of $10 \mu \mathrm{L} \mathrm{min}{ }^{-1}$. Polar impurities were removed by running the system isocratically at $100 \% \AA$ at a flow rate of $5 \mu \mathrm{min}^{-1}$ for $6 \mathrm{~min}$. Finally, tryptic peptides were loaded onto the analytical column and separated using a linear acetonitrile gradient of $5-35 \%$ B for $155 \mathrm{~min}$ at a 
flow rate of $300 \mathrm{~nL} \mathrm{~min}^{-1}$. The LC eluant was injected into the mass spectrometer by means of an Easy-spray source (Thermo Fisher Scientific). All $\mathrm{m} / \mathrm{z}$ values of eluting ions were measured in an Orbitrap mass analyzer, set at a resolution of 70000. Data dependent scans were employed to automatically isolate the 20 most abundant ions and generate fragment ions by higher energy collisional dissociation (HCD) in the quadrupole mass analyser. Only peptide ions with charge states of $2^{+}$and above were selected for fragmentation. Finally, the measurement of the resulting fragment ions was performed in the Orbitrap analyser, set at a resolution of 17500.

\section{Data processing}

Data acquired in DDA mode was analysed by means of either the Paragon $^{29}$ (ProteinPilot software, AB/Sciex, v. 4.5.0.0, 1654) or the Mascot search algorithm (Matrix Science, version 2.3.02) using the $S$. cerevisiae S288C translated ORF database (based on SGD genome version R64-1-130). 156 common contaminant ions (AB/Sciex) were excluded from subsequent analysis. For Paragon searches, we used the following settings: Sample type: Identification; Cys Alkylation: Iodoacetamide; Digestion: Trypsin; Instrument: TripleTOF5600; Special Factors: none; Species: S. cerevisiae; Search effort: Thorough ID; Results Quality: 0.05 . Only peptides with a confidence score of $>0.05$ were considered for further analysis. For Mascot searches, the data was pre-processed using PeakView (AB/Sciex, Triple TOF v. 1.2.0.3) or Protein Discoverer (Thermo Scientific, v. 1.3) setting carbamidomethylation of cystein (C) as a fixed modification, oxidation of methionine $(\mathrm{M})$ as variable modification and allowing a maximum of 2 missed cleavages. Fragment mass tolerance was set to $0.8 \mathrm{Da}$, and Instrument type was ESI-TRAP. Peptides under a significance threshold of 0.05 were regarded as acceptable.

For the extraction of data acquired in SWATH mode, an ion library for yeast was generated from data acquired in data dependent mode. Briefly, a whole proteome yeast digest obtained with the RapidACN procedure was subjected to high $\mathrm{pH}$ reverse phase chromatography (Waters, BEH C18, 2.1 $\times 150 \mathrm{~mm}, 1.7 \mathrm{~mm}$ ) and 20 fractions were collected across a linear gradient of $0-56 \%$ ACN in $20 \mathrm{mM}$ ammonium formate for $74 \mathrm{~min}$. Solvents were removed by vacuum centrifugation and peptides were resuspended in $5 \%$ ACN/ $0.1 \%$ formic acid. Yeast tryptic peptides were then supplemented with $1 \times$ iRT standard peptides (Biognosys) and analysed on the TripleTOF platform. Spectral data were acquired in DDA mode and analysed using the Paragon search strategy as described above. Detected peptides were then corrected for retention time shifts, and the corresponding spectra were combined leading to a library containing 2800 unique yeast proteins. For extraction of SWATH data and peptide quantification Spectronaut 3 (Biognosys) and Skyline ${ }^{31}$ was used. In parallel, Skyline was also used for quantification of peptides from data dependent acquisition experiments. Subsequent data analysis was performed with R, ggplot2 package and custom-built scripts. GO analysis was based on the SGD Gene Ontology Slim Mapper.

\section{Results}

Protocol selection and overall assessment

For this comparative study we selected an in gel digest method adapted from ${ }^{19}$, conducted in combination with an SDS-based and native protein extraction, two filter-aided (FASP (Filter Aided Sample Preparation) adapted from ${ }^{32}$ and a recent enhancement termed eFASP, (adapted from ${ }^{33}$ ), and two in solution procedures (RapiGest, adapted from ${ }^{22}$, and RapidACN adapted from ${ }^{16}$ ). There characteristics, as detailed below, are summarized in Figure 1. All procedures are given in lab-protocol format as Supplementary protocol 1 to Supplementary protocol 6.

\section{In gel digestions}

In gel digestions are popular sample preparation methods as they are convenient, and offer a simple way of protein pre-fractionation through gel slicing and removal of small or high-molecular contaminants that could interfere with trypsin digestion. These approaches are compatible with multiple sample extraction buffers, can easily be combined with gel staining that does not interfere with protein digestion $^{34-36}$, and thus provide a visual quality control over the protein sample. However, casting and running the gels render these protocols time consuming; hence the protocols are of relatively low throughput. In this study, we benchmarked in gel digestion in combination with both SDS-containing (Supplementary protocol 1) and SDS-free protein extraction Supplementary protocol 2) (In gel/SDS

\section{Protocol characteristics}

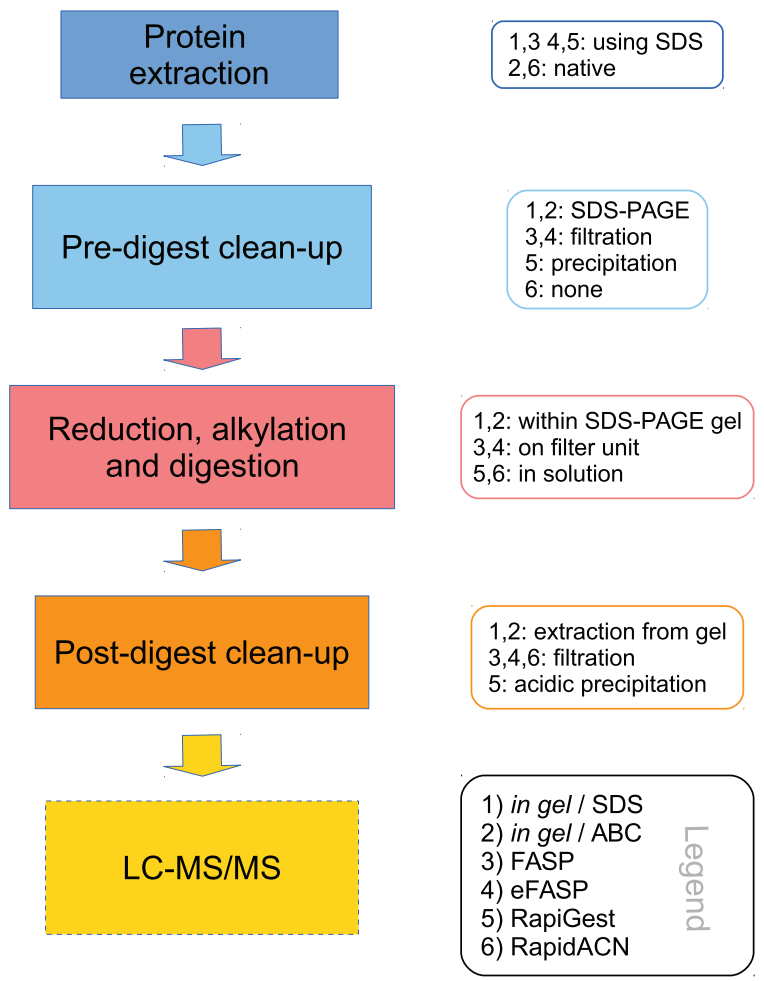

Figure 1. Characteristics of label-free sample preparation methods. Left panel: Schematic overview of the different steps in an LC-Ms/MS sample preparation method Right panel: Main characteristics of the protocols compared in this study. Detailled protocols are given in the Supplementary material. Supplementary protocol 1: In gel/SDS; 2: In gel/ABC; 3: FASP; 4: eFASP; 5: RapiGest; 6: RapidACN. 
and In gel/ABC, respectively ${ }^{19}$, Table 1). SDS-PAGE was however not used as a tool for pre-fractionation. In order to compare in gel methods with filter-aided and in solution digestion, the full mass range was processed and measured at once.

\section{Filter-aided sample preparation}

The second set of assessed protocols involves digestion on filter units. These protocols are popular due to their flexibility and due to the fact that they facilitate a simple handling and require only a modest hands-on time ( $\sim 3 \mathrm{hrs})$. The first protocol tested, FASP ${ }^{32}$ involves a dual protease digest (LysC and trypsin), while the second filter-aided procedure (here called eFASP) is a stepwise-optimized version of FASP by Shevchenko and colleagues ${ }^{21}$ that involves protein precipitation.

\section{In solution digestions}

The final two protocols tested in this study perform protein digestion in solution. The first protocol is based on the proprietary, acid degradable detergent RapiGest (Waters ${ }^{37}$ ), included in a protocol derived from Von der Haar et al. ${ }^{22}$. This protocol involves protein precipitation, which renders the RapiGest procedure more laborious as compared to the second in solution protocol, termed RapidACN. This rather simple method is based upon a tryptic digest in acetonitrile that is combined with a filter-based sample cleanup'. The RapidACN method requires the least number of handling steps and lowest hands-on time ( $2 \mathrm{hrs}$ per sample), overall facilitating the highest throughput among the tested procedures.

\section{Protein identification and compartment specificity}

The six protocols, provided as detailed protocols in the Supplementary materials, were used to process an identical, full proteome sample of Saccharomyces cerevisiae. This single cellular eukaryote possesses a proteome of medium complexity $(6,000-7,000$ protein coding genes ${ }^{38}$ ) and has served as a reference organism in many landmark proteome studies ${ }^{29,39-41}$. Here, the use of yeast facilitated sampling from a single culture, bypassing the possibility of biological variability occurring between the samples analyzed. However, once proteins are extracted, these protocols are fully applicable to process samples obtained from other species as well. To process the yeast pellets, the protocols were executed as closely as possible to their original recipes (with unavoidable minor deviations highlighted in the Protocol section), both in full triplicates (= protocol triplicates), and in injection replicates for comparing the acquisition methods (= injection triplicates). Samples were analysed on a hybrid quadrupole time of flight (TripleTOF5600, AB/Sciex) mass spectrometer for DDA and SWATH acquisition, or on a hybrid quadrupole orbitrap mass spectrometer (QExactive, Thermo Scientific) for DDA acquisition. DDA database searches were conducted using Mascot (for TripleTOF5600 and QExactive, Matrix Science, ${ }^{42}$ ) or ProteinPilot ${ }^{43}$ (for TripleTOF5600, AB/Sciex), whilst SWATH data was processed with Skyline ${ }^{31}$ and Spectronaut ${ }^{44}$ (Biognosys) software.

It is noteworthy that in this study the analytical setup was adapted for quantification and not to maximize the number of protein identifications. This involved the injection of low amounts of sample (equalling $1 \mu \mathrm{g}$ digest per protocol) to prevent column overload and largely overrunning of the dynamic range. Moreover, to allow a direct comparison of the protocols, data was recorded in single injections and samples were not pre-fractionated. This strategy yielded highly reproducible quantification results, achieving up to $<5 \%$ coefficient of variance $(\mathrm{CV})$ values in label-free replicate injections for some protocols, as shown below.

\section{Digest efficiencies}

As an indicator of the quality of tryptic digests, we first assessed the relative occurrence of partially cleaved peptides in data obtained from triplicate injections on the TripleTOF platform. All filter-aided and in solution protocols yielded reasonable digestion efficiencies as revealed by an analysis with both Paragon (AB/Sciex, Figure 2a) and Mascot (Matrixscience, data not shown) search engines. Both in solution and the eFASP procedure yielded arginine- and lysine cleavages in a similar ratio as found in the yeast proteome, with the lowest number of spectra assignable to missed cleavage tryptic sites found in the RapiGest dataset (Figure 2a, and Figure 2b). In the fourth protocol, FASP, however, we found lysine cleavages overrepresented compared to arginine cleavages (Figure 2b). This indicates that the presence of LysC in this protocol increased the overall digestion efficiency of lysine residues; however this may introduce a bias in (absolute) quantification experiments, overrating lysine over arginine peptides in quantification. With the employed in gel protocols we obtained a significant higher number of spectra that corresponded to uncleaved peptides (Figure 2a). Incomplete cleavage of peptides can render a sample preparation unsuitable for absolute, but also for relative quantification, as the rate of cleavage may not be reproducible between replicates ${ }^{9}$. For this reason, we consider the in gel protocol as employed (without prefractionation on the whole-proteome sample) to be potentially erroneous in protein quantification and identification, and excluded the data from the assessment of protein quantification quality. This result however does not exclude the possibility that on other samples, or with modified in gel protocols, acceptable cleavage efficiencies are achieved, and thus, this result should not be interpreted as a critique of in gel methods in general.

\section{Protein identification}

The number of detected peptides correlated with the sum of recorded total peak area, confirming that the instrument was operating within its dynamic range (Figure 2c). The yield of detected peptides (Figure 2c) and proteins (Figure 2d) revealed different performance of the tested protocols. For both data dependent (DDA) and SWATH acquisition, the two in solution protocols (RapiGest and RapidACN) gave the highest number of detectable peptides and proteins. Filter-based FASP and eFASP protocols ranked in the middle range, whilst a significantly lower number of proteins were detected from the in gel digests. Of note, SDS-based compared to native protein extraction increased the number of membrane protein detections in the in gel procedure, but in total a higher number of peptides were obtained in the natively extracted samples. To exclude that these results were platform specific, we injected the same samples on a QExactive mass spectrometer, operating with a different HPLC system and column (Dionex Ultimate 3000; $2 \mu \mathrm{m}$ particle size $\mathrm{C} 18,75 \mu \mathrm{m}$ i.d. $\times 50 \mathrm{~cm}$ column, see methods section). However, the number of protein IDs obtained with the two platforms correlated linearly, indicating that the ID performance of the tested protocols is platform independent (Figure 2d, Inset). 

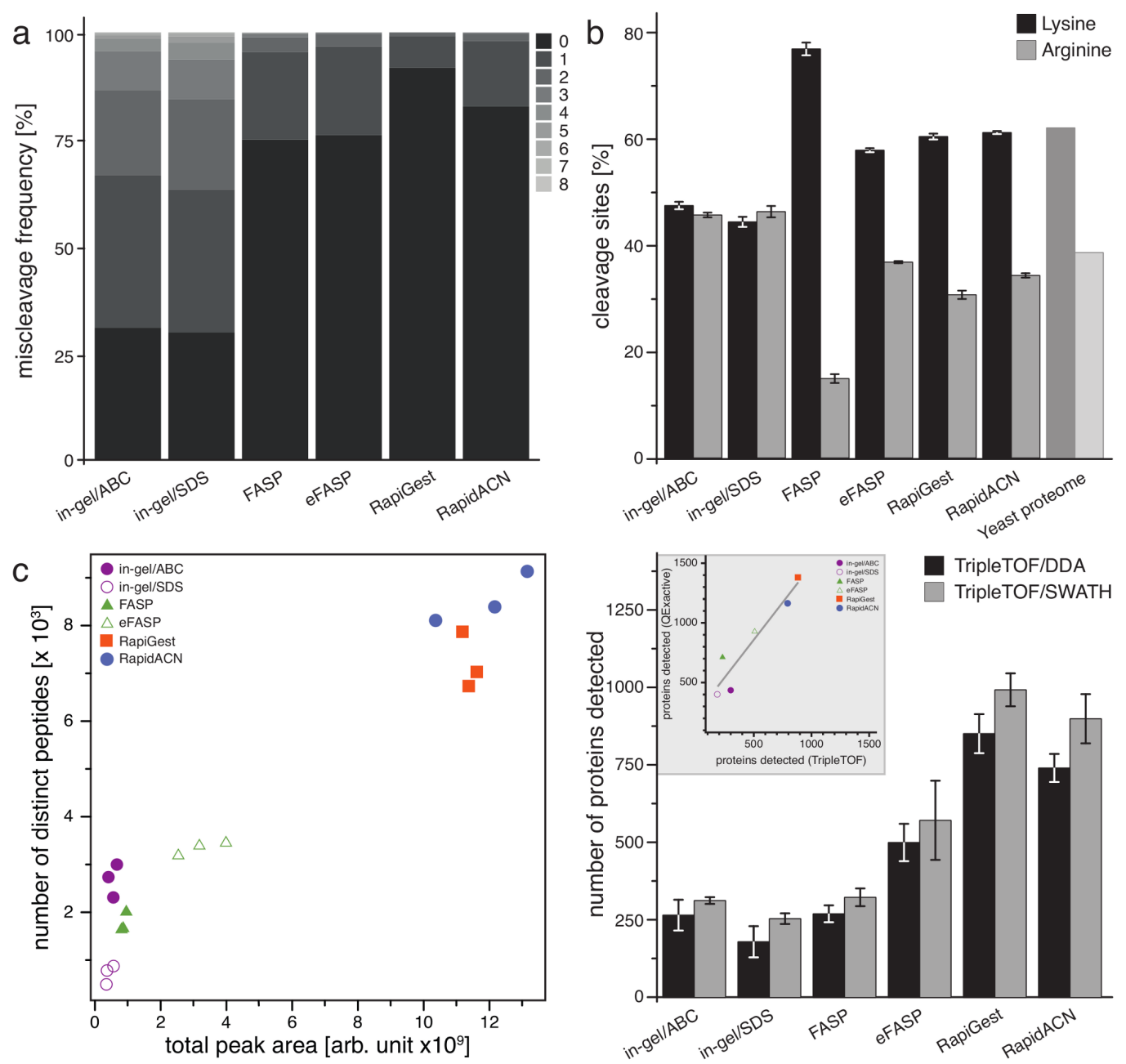

Figure 2. Protein identification in label-free sample preparations. (a) Proteolytic digestion efficiencies. Trypsin or LysC/trypsin (FASP) digestion efficiencies expressed as relative occurrence of spectra that could be assigned miscleaved peptides $(n=3)$. (b) Amino acid specificity of proteolytic digestion. Relative occurrence of identified peptides with C-terminal lysine or arginine, compared to the average frequency of these amino acids across all individual proteins identified ( $n=3$, Error bars $=+/-$ S.D.) (c) Identified peptides differ per protocol, and correlate with the total peak area as recorded in a DDA experiment. 18 samples derived from the same yeast culture were processed with six protocols in triplicates, and analyzed on a TripleTOF5600 instrument. The number of identified peptides correlates with the total peak area recorded, and indicates the highest identification rate in solution digests, followed by filter-aided, and in ge/ procedures. (d) Detection of proteins by DDA or SWATH in a label-free experiment. Samples were analyzed in triplicates both for DDA and SWATH acquisition on a TripleTOF5600 instrument, data was searched using paragon (DDA), and Spectronaut (SWATH). SWATH increased the number of detectable proteins in combination with the in solution protocols. In solution protocols RapidACN and RapiGest led to the detection of up to 1000 proteins in single injections, followed by FASP and eFASP, which gave rise to between 250 and 750 proteins, and in gel injections that yielded 300 proteins IDs. Inset: A comparison of protein IDs for the TripleTOF and QExactive platform shows a linear correlation for the protocols investigated. Data was searched using Mascot $(n=3$, Error bars $=+/-$ S.D. $))$.

Additionally, we tested to what extent injecting higher amounts of sample or pre-fractionation would increase the number of identifiable proteins. Single injection of 10 times the RapidACN sample increased the number of identifiable proteins by $34 \%$ to 1550 (QExactive), while high-pH RP HPLC pre-fractionation of a RapidACN digest led to the identification of 2800 proteins (TripleTOF). Similar tendencies were observed with the other protocols as well, indicating that when combined with sample pre-fractionation, all protocols and both platforms are suitable ID-optimized experiments, as addressed in other studies.

To be able to compare data dependent (DDA) and data independent (DIA) acquisition in terms of protein detection, we then analysed the samples using SWATH mode. Overall, when setting the highest quality threshold on SWATH-detected peptides (Spectronaut Q value $<0.01)$, SWATH and DDA detected a comparable number 
of proteins for the in gel and FASP procedures. However, SWATH outperformed DDA in the samples with high peptide content, RapiGest and RapidACN, leading to a modest but consistent increase in protein detection numbers (Figure $2 \mathrm{~d}$ ).

\section{Performance of sample preparation methods in covering} the variety of the proteome

Next we used the TripleTOF/DDA data to assess whether the protocols covered a similar set of proteins. A subset of 368 proteins overplayed between protocols 3, 4, 5 \& 6 (all filter-aided and in solution protocols), while the filter-aided protocols (Supplementary protocol 3 and Supplementary protocol 4) overlapped for 479 proteins, and the in solution protocols (Supplementary protocol 5 and Supplementary protocol 6) for 915 proteins (Figure 3a). Due to high occurrence of uncleaved peptides, which may affect protein identification, the in gel methods are omitted from this illustration. However, the proteins identified in the in gel samples were to $>95 \%$ covered by in gel and in solution methods as well (data not shown.) All other protocols however also covered specific sets of proteins. RapiGest yielded the highest absolute number of unique IDs, while eFASP provided the highest percentage. Hence, in targeted proteome studies, sample preparation with different protocols might be considered in order to increase the probability of quantifying the desired target.

We next assessed whether these differences correlated to the coverage of cellular localisations. The tested protocols gave high coverage of the GO term cytosol, and performed equally on the a
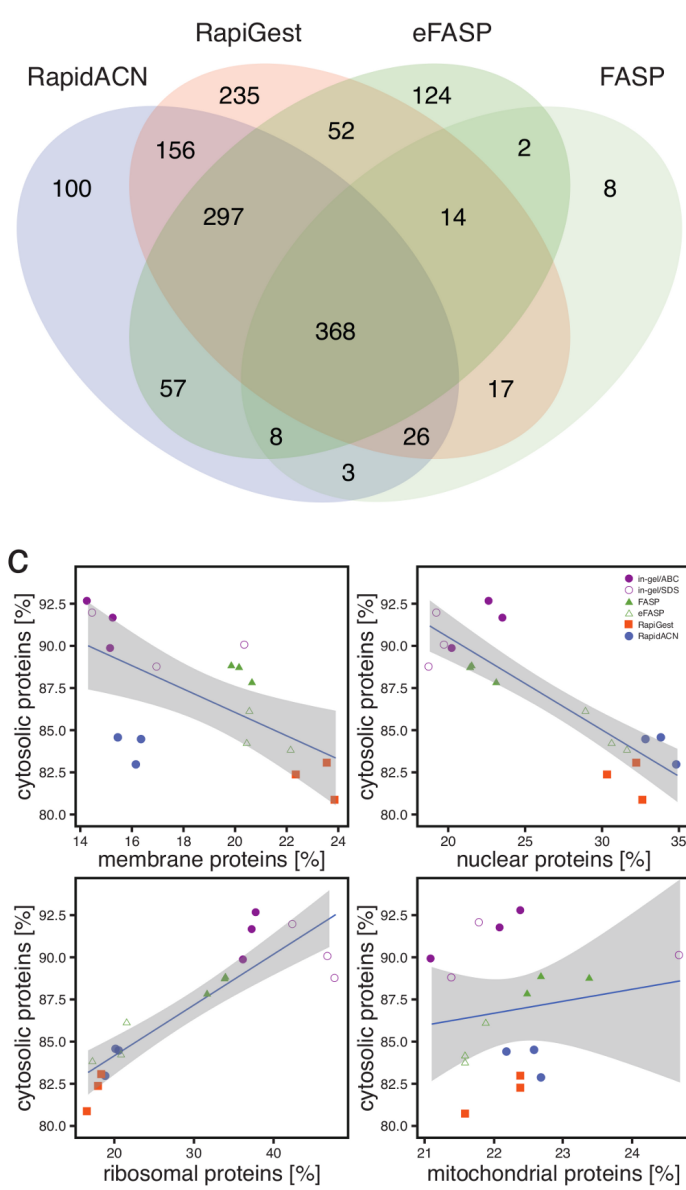
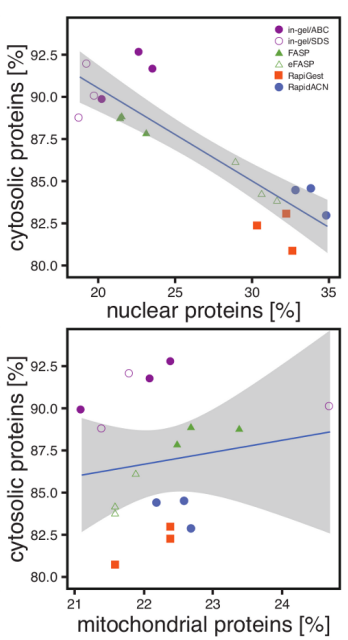

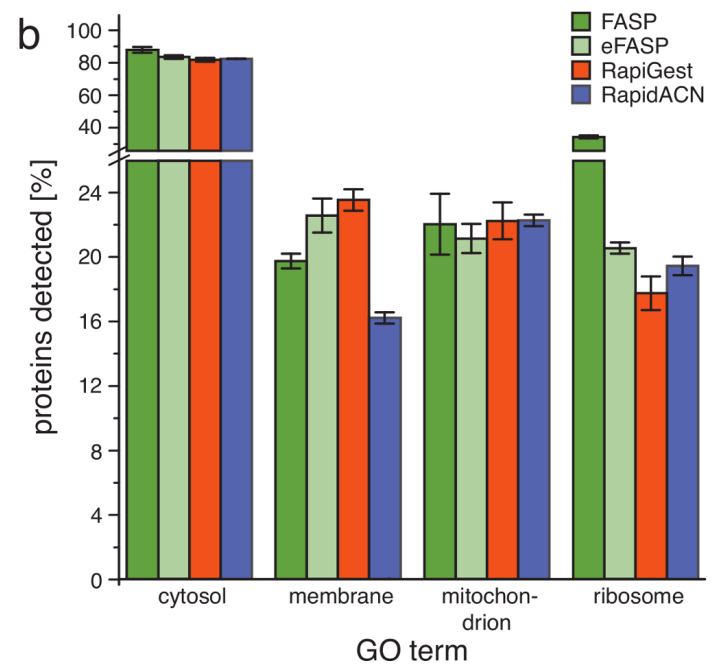

Figure 3. Protocols cover cellular compartments differently. (a) RapiGest and eFASP cover a unique space in the proteome. Identified proteins were visualised in a Venn diagram, excluding the in ge/ protocols. The RapiGest procedure yielded most unique IDs, followed by eFASP and RapidACN $(n=3)$. (b) SDS-containing protocols are best suited for the extraction of membrane proteins. For the analysis of annotated functions in each protocol, selected GO terms were expressed as percentages of identified proteins. While cytosolic proteins were not enriched in any protocol, membrane proteins were preferentially detected in the SDS-containing protocols. $(n=3$, Error bars $=+/-$ S.D.) (c) Filter-aided sample preparations yield a balanced representation of the proteome. The identified proteins were plotted against the percentage of proteins annotated by the GO term cytosol, in order to illustrate the similarity of extraction properties. The protocol properties required for efficient extraction of membrane and nuclear proteins is inversely correlated with the extraction efficiency for cytosolic proteins, while there is a positive correlation with ribosomal proteins. 
mitochondrial proteome (Figure 3b, see Supplementary Figure S2 for a complete overview of GO terms). However, different results were obtained for membrane proteins. The lowest relative content of membrane proteins was obtained for those protocols that extract proteins under non-denaturing conditions, namely RapidACN and in gel/ABC. Conversely, most membrane proteins were detected in the detergent-rich protocols, eFASP and RapiGest. Overall, FASP and eFASP yielded the most balanced representation of both the membrane and cytosolic fraction, while RapidACN data exhibited the strongest bias towards cytosolic and against membrane proteins (Figure 2c).

Finally, we tested whether the protocols covered the proteomic mass range and charge state equally. The proteomic mass range was similarly represented by all protocols with a slight positive bias towards large proteins in all protocols (Supplementary Figure 1a). The procedures, however, differed in the representation of proteins with a certain isoelectric point $(\mathrm{pI})$. The best representation of the proteome $\mathrm{pI}$ distribution was obtained with RapiGest (deviation coefficient $(\mathrm{d})=2.4)$, followed by FASP $(\mathrm{d}=2.8)$ and RapidACN $(\mathrm{d}=2.9)$ (Supplementary Figure 1b). In gel procedures scored least as they were negatively biased towards neutral proteins, and achieved a lower d value of 5.3 or 5.9 for in $\mathrm{gel} / \mathrm{ABC}$ or in $\mathrm{gel} / \mathrm{SDS}$, respectively.

\section{Label-free quantification}

Next, we compared the protocols for their consistency in label-free quantification. As illustrated in Figure 2c, the number of identified peptides correlated with the sum of total peak area recorded, hence all procedures in principle lead to quantitative results. To be able to compare the protocols, we expressed the variation of signal intensities obtained from replicate sample preparations as coefficient of variation (CVs), and we plotted the frequency of CVs in twodimensional distribution histograms ('violin plots', Figure 4a).
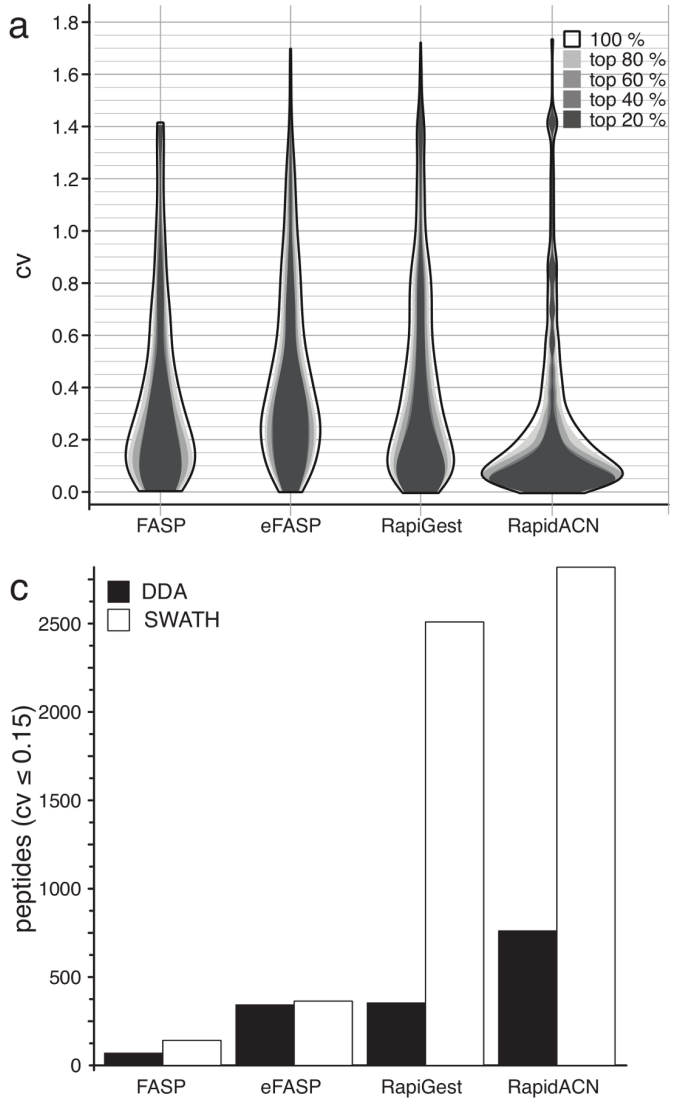

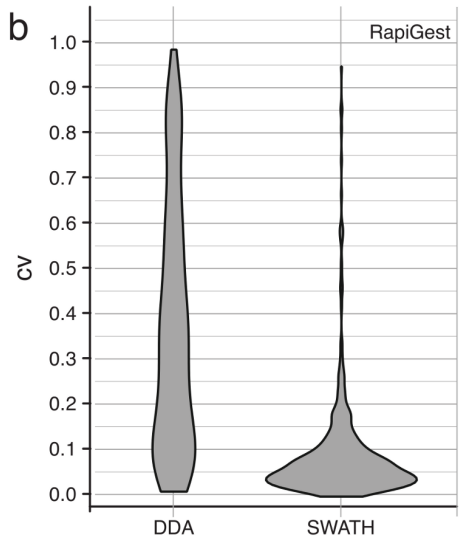

Figure 4. In solution digestion leads to stable results in label-free proteomics. (a) The distribution maximum of coefficients of variation (CV) of the selected protocols varies between $\mathbf{0 . 0 7 5}$ and $\mathbf{0 . 2}$. CV values obtained for protocol triplicates are shown as twodimensional distribution histograms ('violin plots'). Quantification in DDA experiments were consistent over the dynamic range, as CV values only marginally changed when filtering by peptides according to their abundance ( $80 \%, 60 \%, 40 \%$ or $20 \%)$. CV likelihood maxima of all protocols were below $20 \%$, while RapidACN lead to the most reproducible results $(C V=7 \%)(n=3)$. (b) Stability in a quantification experiment is improved by data-independent acquisition. CV values for the same set of peptides measured with SWATH and DDA using the RapiGest protocol, as shown in a two-dimensional distribution histogram. Whereas there was a high signal variation in DDA acquisition, the variation could be largely reduced in SWATH acquisition. (c) In solution protocols yield the highest number of peptides suitable for label-free quantification. The number of peptides with a CV $<0.15$ as determined in DDA and SWATH acquisitions. The number of highly reproducible peptides was lower for FASP and EFASP, and SWATH acquisition did not improve the performance in combination with these methods. In solution protocols on the other hand did yield a maximum of about 2500 high-quality peptides using SWATH. 


\begin{tabular}{|c|c|c|c|c|c|c|}
\hline Protocol Name & In gel/SDS & In gel/ABC & FASP & eFASP & RapiGest & RapidACN \\
\hline Reference & $\begin{array}{l}\text { Based on } \\
\text { Kaiser et al., } \\
2008\end{array}$ & $\begin{array}{l}\text { Based on } \\
\text { Kaiser et al., } \\
2008\end{array}$ & $\begin{array}{l}\text { Wisniewski } \\
\text { et al., } 2009\end{array}$ & $\begin{array}{l}\text { Shevchenko } \\
\text { et al., } 2012\end{array}$ & $\begin{array}{l}\text { Waters (UK), } \\
\text { based on von der } \\
\text { Haar et al., } 2007\end{array}$ & $\begin{array}{l}\text { Bluemlein } \\
\text { et al., } 2011\end{array}$ \\
\hline Digest & In gel & In gel & Filter-aided & Filter-aided & In solution & In solution \\
\hline Lysis & $4 \%$ SDS, DTT & $0.05 \mathrm{M} \mathrm{ABC}$ & $4 \%$ SDS, DTT & $1 \%$ SDS, EDTA & $\begin{array}{l}2 \% \text { SDS, } \beta-M E \text {, } \\
\text { EDTA }\end{array}$ & $0.05 \mathrm{M} \mathrm{ABC}$ \\
\hline $\begin{array}{l}\text { Protein } \\
\text { precipitation }\end{array}$ & - & - & - & Yes & Yes & - \\
\hline $\begin{array}{l}\text { Additive for } \\
\text { digestion }\end{array}$ & - & - & Urea & nOGP & Rapigest & Acetonitrile \\
\hline $\begin{array}{l}\text { Use of filter } \\
\text { units }\end{array}$ & - & - & for digest & for digest & - & $\begin{array}{l}\text { for sample } \\
\text { clean-up }\end{array}$ \\
\hline Protease & Trypsin & Trypsin & Lys-C + Trypsin & Trypsin & Trypsin & Trypsin \\
\hline Total time & $29 \mathrm{hrs}$ & $29 \mathrm{hrs}$ & $32 \mathrm{hrs}$ & $30 \mathrm{hrs}$ & $30.5 \mathrm{hrs}$ & $26 \mathrm{hrs}$ \\
\hline $\begin{array}{l}\text { (of which } \\
\text { digest) }\end{array}$ & (16 hrs) & (16 hrs) & (20 hrs) & (16 hrs) & (18 hrs) & (18 hrs) \\
\hline Hands on time & $5 \mathrm{hrs}$ & $5 \mathrm{hrs}$ & $3 \mathrm{hrs}$ & $3 \mathrm{hrs}$ & $3.5 \mathrm{hrs}$ & $2 \mathrm{hrs}$ \\
\hline $\begin{array}{l}\text { Consumable } \\
\text { costs }\end{array}$ & $<0.5$ & $<0.5$ & 10.75 & 1.8 & $1(=2 £)$ & 1.95 \\
\hline $\begin{array}{l}\text { Overall } \\
\text { throughput }\end{array}$ & & & $\star$ & $\star$ & $\star \star$ & $\star \star \star$ \\
\hline $\begin{array}{l}\text { Total protein } \\
\text { IDs }\end{array}$ & & & & $\star$ & $\star \star \star$ & $\star \star$ \\
\hline $\begin{array}{l}\text { membrane } \\
\text { proteins }\end{array}$ & & & $\star \star \star$ & $\star$ & $\star \star$ & \\
\hline $\begin{array}{l}\text { CV in label-free } \\
\text { quantification }\end{array}$ & & & $\star$ & & $\star \star$ & $\star \star \star$ \\
\hline \multirow[t]{2}{*}{ Comments } & $\begin{array}{l}\text { + Cost effective } \\
\text { + Matrix } \\
\text { independent }\end{array}$ & $\begin{array}{l}\text { + Cost effective } \\
\text { + Matrix } \\
\text { independent }\end{array}$ & $\begin{array}{l}\text { + Best pl } \\
\text { coverage } \\
+ \text { Cell } \\
\text { compartments }\end{array}$ & + Lipid removal & $\begin{array}{l}\text { + High ID } \\
\text { numbers } \\
+ \text { Low CVs } \\
+ \text { Good coverage } \\
\text { of membrane } \\
\text { proteins }\end{array}$ & $\begin{array}{l}\text { + Highest } \\
\text { throughput } \\
+ \text { Lowest CVs } \\
+ \text { Highest No of } \\
\text { quantifiable } \\
\text { peptides }\end{array}$ \\
\hline & $\begin{array}{l}\text { - Low ID } \\
\text { numbers }\end{array}$ & $\begin{array}{l}\text { - Low ID } \\
\text { numbers }\end{array}$ & $\begin{array}{l}\text { - Dual protease } \\
\text { digest }\end{array}$ & $\begin{array}{l}\text { - Traces of nOGP } \\
\text { in sample } \\
\text { - High CV }\end{array}$ & $\begin{array}{l}\text { - Dependent on } \\
\text { proprietary } \\
\text { reagent } \\
\text { - Traces of } \\
\text { detergent may } \\
\text { reside }\end{array}$ & $\begin{array}{l}\text { - Low number of } \\
\text { membrane } \\
\text { proteins }\end{array}$ \\
\hline
\end{tabular}

DDA acquisition resulted in a CV maximal likelihood of $20 \%$ for eFASP, FASP and RapiGest. Although most peptides showed a variation of this magnitude, it is worth noting that there was a considerable spread of $\mathrm{CVs}$ in all three protocols, with some peptides showing as much as $140 \%$ variation. By far the highest signal reproducibility with a $\mathrm{CV}$ maximal likelihood of $7 \%$ was obtained with the RapidACN protocol (Figure 4a), indicating best suitability of this protocol in label-free quantification.
Next, we counted the number of precisely quantified peptides, defined as peptides with a $\mathrm{CV}<15 \%$. Also in this measure, the RapidACN procedure outperformed the other methods, while RapiGest, and eFASP performed second and third best, respectively (Figure 4c). Not covered in this benchmark is the performance of the individual protocols in repeated sample preparation over longer periods, i.e. weeks to months. This might be required for particular sets of samples that can not be stored without a protease digest, yet 
require sampling on different days to address a specific biological question.

Finally, we tested whether SWATH analysis improved label-free quantification. Comparing the $\mathrm{CV}$ distribution of peptides detected both in DDA and SWATH data using the RapiGest protocol (Figure 4b), we discovered a much more focussed CV distribution around a maximal likelihood of 5\% in SWATH, compared to a maximal likelihood of $20 \%$ in DDA mode. When counting the number of precisely quantified peptides $(\mathrm{CV}<0.15)$, SWATH led to an increase of up to a factor of two and five for RapidACN and RapiGest, respectively (Figure 4c). Hence, SWATH acquisition greatly improved the CV stability with label-free acquisition, the result of which is that a substantial number of peptides were precisely quantified.

\section{LC-MS/MS spectral information}

31 Data Files

http://dx.doi.org/10.6084/m9.figshare.870470

\section{Discussion}

Stable isotope labelling is a popular and reliable strategy in quantitative proteomics, yet it has limitations that arise from an increased analyte load in the precursor ion (MS1) space, and the way standards are produced or incorporated: For instance, targeted protein quantification using AQUA peptides ${ }^{45}$, achieves absolute quantification though comparison between the peak areas of light and chemically synthesized heavy-isotope labelled peptides of known concentration. However the costs for such peptides limits the number of proteins quantifiable ${ }^{7,45}$. An alternative strategy is the nontargeted chemical labelling of proteins and peptides with isobaric tags (i.e. iTRAQ, TMT), facilitating multiplexing of proteome samples and providing relative simultaneous quantification of labelled peptides ${ }^{8,46}$. However, frequent co-selection of the reporter ions reduces both the accuracy and precision of quantification ${ }^{47,48}$ Such a problem is circumvented when metabolic incorporation of isotope-labelled amino acid residues (i.e. $\mathrm{SILAC}^{49}$, or recent extensions like instance NeuCODE which is based on different nuclear mass dependent on the isotope combination integrated ${ }^{50}$ ), is used to create isotope-labelled standards in vivo. However, this approach is limited to heterotrophic species that consume lysine and arginine from the culture medium, and is in practice limited to tissue culture as the attempt to introduce labelling in animal models becomes extremely expensive ${ }^{51}$.

Label-free experiments circumvent the use of isotope labelled standards, thus are not affected by the above-mentioned limitations. As such, they are ideal complements when isotope labelling becomes a limitation. However, they lack possibilities to correct for selective sample loss, and hence are more sensitive to variations in sample preparation and instrument performance. The protocols employed thus require more rigorous validation.

\section{In gel digests}

Our comparison starts with a classic in gel digestion method ${ }^{19}$, which is tested in combination with SDS-containing- and SDS-free protein extractions (Supplementary protocol 1 and Supplementary protocol 2). These popular cost-effective procedures are based on the principle that a protein sample is denatured and separated on an SDS-PAGE gel prior to reduction, alkylation and protease digestion that are conducted within the gel matrix. The gel fulfils the function of sample clean up, as it removes positively charged contaminants as well as large macromolecules (i.e. nucleic acids) and small chemical compounds, and is very robustly applied to a large variety of sample types. Furthermore, the excision of individual bands or mass ranges make in gel digestions attractive wherever a simple sample pre-fractionation is required. Proteome pre-fractionation in gel (geLC-MS) has resulted in a significant proteome depth and dynamic range in studies were $>5000$ distinct proteins were confidently identified and quantified ${ }^{52,53}$. Moreover, in gel digests have proven ideal when gel bands resulting from individual proteins are to be identified (i.e. for studying protein complexes). In the present study however, we did not make use of sample pre-fractionation. In order to achieve comparability with the other protocols, the full mass range was processed for the digest (see Methods section, and Supplementary protocol 1 and Supplementary protocol 2). This treatment led to a full representation of the proteomic mass distribution (Supplementary Figure S1). Under these circumstances however, the classic in gel protocol applied proved the least suitable method for label-free quantification. The protocol was the most time consuming, yet yielded a significant number of miscleaved peptides, and we detected the lowest number of proteins and peptides in total. Differences between SDS-free and SDS-containing sample extraction concerned the relative content of membrane proteins identified, which was higher in the latter, whereas the native extraction resulted in a higher number of proteins identified in total. This result should however not be interpreted as a general critique on in gel methods, as in combination with protein pre-fractionation (gel-slicing), they have proven for well-suitable sample preparation methods in ID experiments ${ }^{52,53}$.

\section{Filter-aided sample preparation}

The dependence on filter units in the two tested filter-aided sample preparation procedures, FASP $^{32}$, and one of its recent extensions (here called eFASP ${ }^{21}$ ), increases the material costs, but has advantages for sample handling and throughput. Indeed, handling of the first protocol, FASP, was efficient and achieved a reasonable throughput with modest hands-on time (Supplementary protocol 1). In protein identification, FASP achieved the highest relative amount of detected membrane proteins. Hence, this protocol might be an ideal choice when membrane proteins are to be studied.

FASP was the only protocol in this study where digestion was carried out using a combination of proteases, LysC and trypsin. Similar to previous reports ${ }^{54}$, we observed that the addition of LysC increased the relative digestion efficiency. However, this resulted in an over-representation of lysine over arginine containing peptides, which may lead to bias in cases where this protocol is used in an absolute quantification experiment. In label-free quantification, FASP performance was average both in the number of precisely quantified peptides and in the $\mathrm{CV}$ values obtained for replicative sample preparations. It is important to mention in this context that the performance of FASP procedures is dependent on the filter units that are available from different manufacturers, but exactly the 
same filter unit which was used in the original FASP paper $^{32}$ is no longer available. In this study we have chosen Amicon Ultra- $0.53 \mathrm{k}$ for both FASP based protocols as used in eFASP by Shevchenko et al. ${ }^{21}$, as their cut-off rate of $3 \mathrm{kDa}$ is the closest to the addressable mass range of the SWATH acquisition $(400-1200 \mathrm{~m} / \mathrm{z}$ ). Further work from Wisniewski et al. demonstrated that also larger cut-off rates up to 50k are suitable in combination with the FASP protocol, and can improve the identification rate of larger proteins and peptides ${ }^{55}$. Moreover, in difference to the other protocols tested in this study, the tryptic digest in FASP is conducted in a very high concentration of urea. A simple protocol adaptation to influence the tryptic digest could thus be to change the buffer conditions, i.e. to a buffer as used in eFASP $^{21}$ (Supplementary protocol 4).

The second filter-aided protocol, eFASP, represents a stepwise optimisation of FASP, and contains several alterations compared to its predecessor $^{21}$ (Supplementary protocol 4). The protease digest is performed using trypsin only, and the protocol includes a lipid removal step and uses n-octyl-D-glucopyranoside (nOGP) as the detergent in sample preparation. The latter might be regarded as an undesirable addition to the sample, as nOGP can interfere with electrospray ionisation. Indeed, despite all washing steps, we could detect traces of nOGP in the MS/MS spectra, and the collection of MS data was reduced at the time a nOGP sodium adduct eluted (data not shown). Despite this, the modifications made for eFASP clearly improved the performance in protein and peptide identification. However, in our hands, they did not improve the precision in label-free quantification, the performance of FASP and eFASP in this measure was comparable (Figure 4). Hence, the main advantage of eFASP over FASP lies in improvements in protein identification and proteome coverage.

\section{In solution digestion}

The first method tested (Supplementary protocol 5) is based upon the commercial reagent RapiGest (3-[(2-methyl-2-undecyl-1,3-dioxolan-4-yl)methoxy]-1-propanesulfonate ${ }^{37}$ (Waters)), an anionic detergent which is depleted from the sample through acidic cleavage. The established protocol $^{22}$ contains a step for lipid removal and a precipitation step that renders this procedure more laborious compared to the FASP and RapidACN protocols. However, as it does not involve any filter unit, it was most economic in terms of material costs per sample if one disregards the in gel protocols. Moreover, it yielded the highest number of protein and peptide IDs, and it detected the highest absolute number of membrane proteins. In label-free quantification, it scored third best in the average CV for DDA, and second best in combination with SWATH acquisition. Expressed in absolute quantities, this method yielded the secondhighest numbers of precisely quantified peptides. Thus, the RapiGest protocol is a versatile and economic method that may represent the optimal choice in many applications. The only inexplicable issue with this protocol was related to the inefficiency of RapiGest degradation and precipitation in a small subset of samples. Thus care must be taken to avoid its injection in the LC-MS/MS setup.

The second in solution protocol (termed RapidACN ${ }^{9}$, Supplementary protocol 6) is detergent-free and based on acetonitrile in sample processing and proteolytic cleavage followed by clearing samples from high-molecular weight contaminants by a final filtration step. As this protocol is based on a native protein extraction, it identified - in relative terms - the lowest number of membrane proteins. Moreover, as it does not contain an intensive pre-digest sample treatment, functionality of this protocol may omit tissue were such a forefront clean up is mandatory. Despite these limitations, RapidACN performed best in the metric most crucial for robust label-free quantification, a low $\mathrm{CV}$ value in replicate sample digests and injections. Moreover, compared to the other tested methods, RapidACN was simplest in handling, required the least processing steps and only minimal hands-on time ( $2 \mathrm{hrs}$ ), while yielding the second highest number of protein and peptide detection both in DDA and SWATH acquisition methods. Hence, RapidACN might be the most suitable solution for a label-free experiment when the focus is not to quantify membrane proteins, or to analyze tissue that requires extensive clean up.

\section{Data-dependent versus data-independent acquisition}

We chose to perform major parts of this study on a TripleTOF5600 instrument (AB/Sciex), in order to compare data-dependent acquisition (DDA) with data-independent acquisition (DIA). DIA is believed to be advantageous for label-free quantification, as it is not affected by run to run variation, and as MS2 data is reconstructed in chromatograms that resemble selective reaction monitoring $(\mathrm{SRM})^{17}$. Therefore, this technique appears a desirable choice for the label-free analysis of biological time series, that require many samples (replicates over many time-points) to be compared ${ }^{15}$. The design of the TripleTOF5600 quadrupole allows precursor ion selection in a rectangular rather than a Gaussian mass selection window as in other instruments, reducing the co-selection of peptides falling in the adjacent mass windows ${ }^{23}$. In a workflow termed SWATH, the mass range from 400 to $1200 \mathrm{~m} / \mathrm{z}$ is scanned in $25 \mathrm{Da}$ windows, and the merged data used to reconstruct spectral $\left(\mathrm{MS}^{2}\right)$ $\mathrm{m} / \mathrm{z}$ chromatograms ${ }^{17}$. Processing SWATH data with Spectronaut (V. 3.0.337, Biognosys), we compared the performance of DDA with SWATH in protein detection and label-free quantification. In samples with low peptide content, the number of detected proteins with DDA and SWATH was comparable. However, in the in solution protocols that led to highest IDs, SWATH acquisition gave a slight but significant advantage in terms of peptides detected. This indicates that this approach is advantageous in protein detection when coupled with complex matrices. Significantly improvement of SWATH versus DDA was however observed in label-free quantification. The strongest effect of SWATH acquisition was observed when it was used in conjunction with the RapiGest protocol (Supplementary protocol 5), where the number of precisely quantified peptides increased by a factor of five, followed by the combination with RapidACN (Supplementary protocol 6), where this measure doubled (Figure 4c). Of note, SWATH employed in combination with the latter, resulted in an average CV below 5\%, representing a superior value obtained in a label-free experiment. These improvements mainly resulted from a more reliable quantification of peptides in the mid to high abundance range, whereas there was no increased improvement quantification of low abundant spectra over DDA. We assume that this difference could be further optimized by improving the SWATH peak selection algorithms, as noise in the low abundance window results from occasional misassignment of fragment ions to precursors.

\section{Conclusions}

By facilitating label-free quantification, second-generation proteomics techniques enable flexible proteomic workflows. As the 
protocols cover different sets of proteins, the main determinant to select the best suitable method and workflow remains the biological question and the set of proteins to be addressed. Despite this, sample preparation methods differ in precision, sensitivity and throughput. Under the conditions of this benchmark, and under the conditions in our laboratory, a combination of in solution digestion protocols RapiGest or RapidACN with SWATH acquisition yielded optimal results for a label-free proteomics experiment. Achieving reliable quantification at reasonable numbers of detected proteins, label-free quantitative proteomics represents a suitable alternative to isotope labelling in addressing a series of biological problems.

Author contributions

Jakob Vowinckel, Floriana Capuano and Kate Campbell and Michael J. Deery, designed and conducted experiments, Kathryn S. Lilley and Markus Ralser designed experiments, all authors wrote on the paper.
Competing interests

The authors declare no competing interests.

Grant information

This work was funded by the Isaac Newton Trust, the Wellcome Trust (RG 093735/Z/10/Z) to MR, the ERC (Starting grant 260809) to MR and the 7th Framework Programme of the European Union (262067- PRIME-XS) to KSL. M.R. is a Wellcome Trust Research Career Development and Wellcome-Beit prize fellow.

The funders had no role in study design, data collection and analysis, decision to publish, or preparation of the manuscript.

Acknowledgements

We thank our lab members for help in this manuscript, and Pavel Shliaha (University of Cambridge) for help with the RapiGest sample preparation procedures.

\title{
Supplementary material
}

RAW data: The .wiff files of the DDA and DIA acquision used in Figure 2-Figure 4 are downloadable as Supplementary Data. Supplementary table ST1 lists the different file names.

\begin{abstract}
Table S1. Rolling Collision Energy settings of the Triple TOF platform.
\end{abstract}

\begin{tabular}{|lll|}
\hline Charge & Slope & Intercept \\
\hline Unknown & 0.044 & 4 \\
\hline 1 & 0.0575 & 9 \\
\hline 2 & 0.044 & 4 \\
\hline 3 & 0.05 & 3 \\
\hline 4 & 0.05 & 2 \\
\hline 5 & 0.05 & 2 \\
\hline
\end{tabular}

$\left(\right.$ ICEI $=(\text { slope })^{*}(\mathrm{~m} / \mathrm{z})+$ intercept 

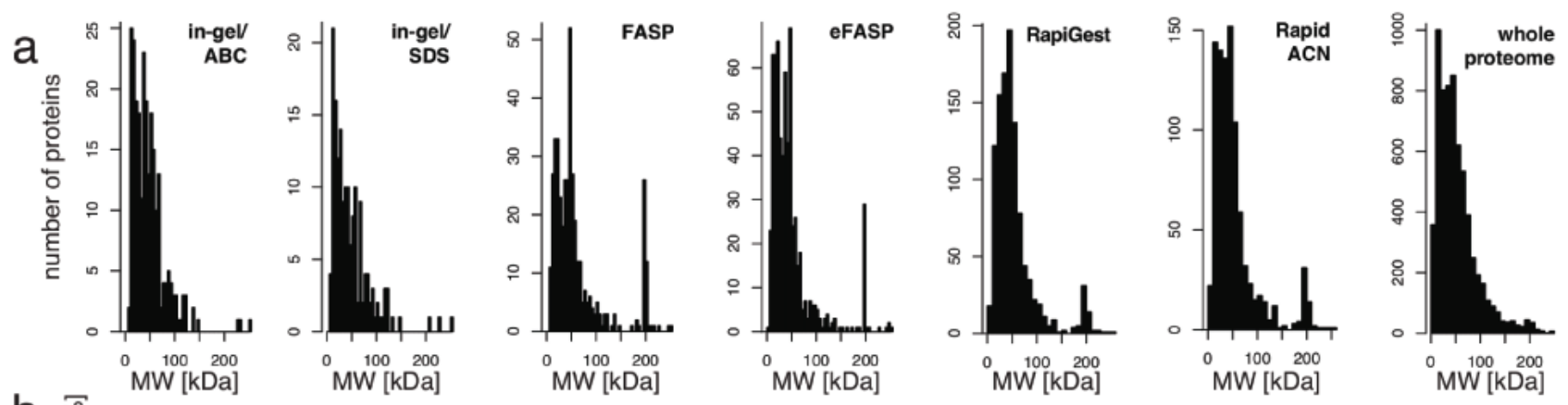

b

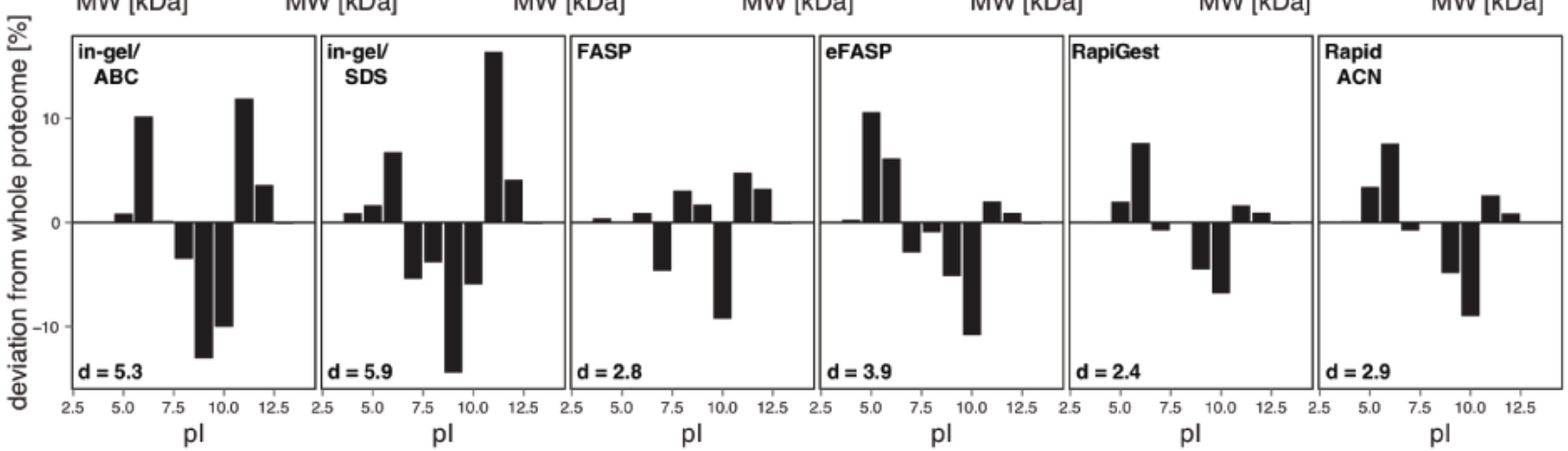

Figure S1. Bias of protein size and pl in sample preparation. (a) The spectrum of protein sizes is well covered for all protocols examined. The number of identified proteins was plotted against the theoretical molecular weight (MW) for each protocol investigated. Although some protocols yielded higher identifications than others, the MW range was well reproduced for all of them when comparing to the whole yeast proteome. (b) Different representations of protein charges. When comparing to the distribution of theoretical protein pl values of the whole proteome, all investigated protocols showed an under-representation of proteins with a pl of 10 . When expressing the total deviation as deviation score d, RapiGest, FASP and RapidACN score best. The $\mathrm{d}$ values were calculated as the sum of all differences in \% compared to the theoretical proteome occurrence multiplied by 0.1 .

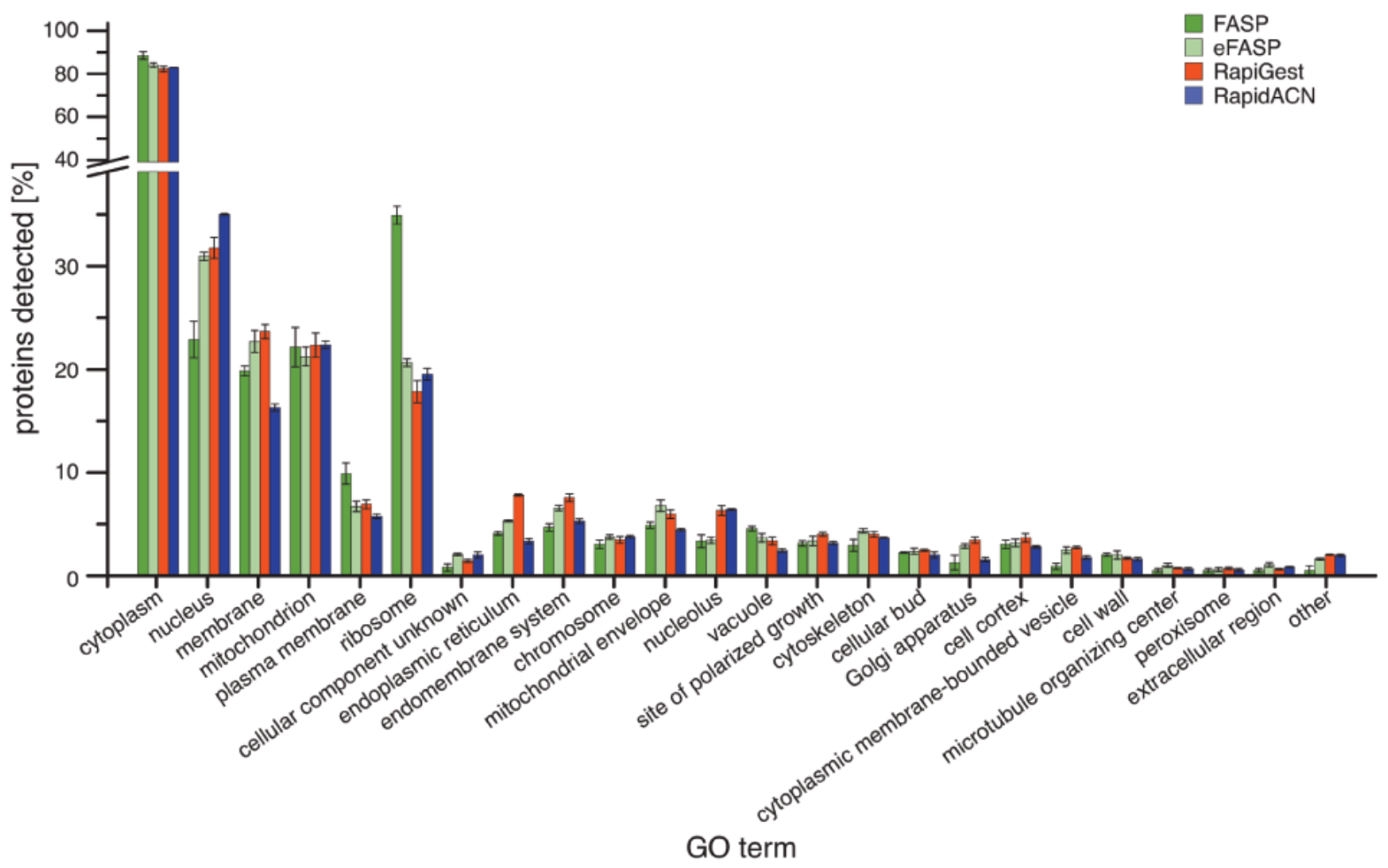

Figure S2. Distribution of GO terms associated with identified proteins. The percentage of GO annotations for each protocol is shown, allowing multiple annotations for individual proteins $(n=3$, Error bars $=+/$ - S.D.). 


\section{Supplementary protocol 1: In-gel digestion in combination with SDS extraction}

(Adapted from Kaiser, P, Meierhofer, D, Wang, X, Huang, L. Tandem affinity purification combined with mass spectrometry to identify components of protein complexes. Methods Mol. Biol. 2008, 439: 309-326)

\section{Materials}

\section{Solutions and reagents}

Lysis buffer: SDT buffer (4\% SDS, $100 \mathrm{mM}$ Tris/HCl $\mathrm{pH}$ 7.6, 0.1 M Dithiothreitol (DTT, Melford Cat No. MB1015)

ABC: 0.05 M Ammonium bicarbonate (Fluka Cat. No. 40867-50G-F) in water

DTT: 0.09 M Dithiothreitol (Melford Cat No. MB1015)

IAA: 0.1 M Iodoacetamide (Sigma Cat. No. I1149-5G) in ABC

Sequencing Grade Modified Trypsin: Stock $0.2 \mu \mathrm{g} / \mu \mathrm{L}$ (Promega Cat. No. V5111)

UPLC/MS grade water

FA: Formic acid

ACN: Acetonitrile

$30 \%$ Acrylamide/0.8\% Bis-acrylamide (Protogel, Geneflow Limited Cat. No. EC-890)

10\% Ammonium persulfate (APS, Sigma Cat. No. A3678-25G)

$10 \%$ Sodium dodecyl sulfate (SDS, Melford Cat. No. S1030)

$1.5 \mathrm{M}$ Tris/ $\mathrm{HCl} \mathrm{pH} 8.8$

$0.5 \mathrm{M}$ Tris/ $/ \mathrm{HCl} \mathrm{pH} 6.8$

BCA Protein assay kit (Pierce Cat. No. 23225)

\section{Equipment}

Protein Gel Casting Stand (BioRad)

Acid-washed glass beads (Sigma G8772-500G)

Protein LoBind tubes (Eppendorf Cat. No. 0030 108.094)

Fast Prep-24 instrument (MP Biomedicals)

Refrigerated bench top centrifuge

Spectrophotometer

Ultrasonic tank (Langford Electronics Limited)

Wet chamber

Vacuum concentrator centrifuge

Method

\section{Sample lysis}

- Add 200 $\pm 10 \mathrm{mg}$ glass beads and $200 \mu \mathrm{L}$ lysis buffer to $30 \mathrm{mg}$ cells (wet weight, equaling $10 \mathrm{OD}_{600}$ units of yeast cells)
- Vibrate the cell suspension in the Fast Prep-24 instrument $\left(4^{\circ} \mathrm{C}\right.$, settings: $\left.6.5 \mathrm{Ms}^{-1}, 20 \mathrm{sec}\right)$. Repeat this step 2 times with a 5 min interval, keep samples on ice between intervals

- Centrifuge at $16,000 \times g$ for $1 \mathrm{~min}$ to sediment the cell debris

- Incubate for $3-5 \mathrm{~min}$ at $95^{\circ} \mathrm{C}$

- Centrifuge at $16,000 \times g$ for $1 \mathrm{~min}$

- Transfer the supernatant to a new reaction tube

- Incubate for $5 \mathrm{~min}$ in an ultrasonic tank to reduce viscosity

\section{Protein quantification}

- Use BCA assay to determine the protein concentration according to the manufacturer's instructions

\section{Sample processing}

\subsection{Protein separation by SDS-PAGE}

- Cast separating (15\% acrylamide/bisacrylamide) and stacking gels (4\%) according to Laemmli (Laemmli, UK. Cleavage of structural proteins during the assembly of the head of bacteriophage T4. Nature. 1970, 227, 680-685)

- Add SDS-PAGE loading buffer to a lysate aliquot containing $50 \mu \mathrm{g}$ protein and incubate at $95^{\circ} \mathrm{C}$ for $5 \mathrm{~min}$ to denature proteins

- Perform electrophoresis for $20 \mathrm{~min}$ at $80 \mathrm{~V}$ and for $45 \mathrm{~min}$ at $20 \mathrm{~V}$ (constant voltage)

- Excise the sample from the gel

\subsection{Excision and in-gel digestion of protein bands}

- Cut the gel slice into small pieces $(1 \mathrm{~mm})$ and place into a new reaction tube

- Add $100 \mu \mathrm{L}$ (or enough to cover) $25 \mathrm{mM} \mathrm{ABC/50 \%} \mathrm{(v/v)} \mathrm{ACN}$ and vortex for $10 \mathrm{~min}$

- Centrifuge at $16,000 \times g$ for $30 \mathrm{sec}$ and remove the supernatant using a gel-loading micropipette tip. Repeat this step for 2 or 3 times

- Evaporate the solvents in a vacuum concentrator centrifuge (approximately $20 \mathrm{~min}$ )

- Add $50 \mu \mathrm{L}$ (or enough to cover) $10 \mathrm{mM}$ DTT in $25 \mathrm{mM} \mathrm{ABC}$ to the dried gel pieces

- Vortex and centrifuge at $16,000 \times g$ for $30 \mathrm{sec}$

- Incubate with the reductive solution at $56^{\circ} \mathrm{C}$ for $1 \mathrm{~h}$

- Remove the supernatant and add $50 \mu \mathrm{L}$ (or enough to cover) $50 \mathrm{mM}$ IAA to the gel pieces. Vortex and centrifuge at 16,000 $\times g$ for $30 \mathrm{sec}$

- Incubate with the alkylation solution in the dark for $30 \mathrm{~min}$ at room temperature, with occasional vortexing. Centrifuge at $16,000 \times g$ for $30 \mathrm{sec}$ 
- Remove the supernatant. Add $\sim 100 \mu \mathrm{L} 25 \mathrm{mM}$ ABC to the gel pieces. Vortex for $5 \mathrm{~min}$ and centrifuge at $16,000 \times g$ for $30 \mathrm{sec}$

- Remove the supernatant and add $\sim 100 \mu \mathrm{L}$ (or enough to cover) $25 \mathrm{mM} \mathrm{ABC} / 50 \%(\mathrm{v} / \mathrm{v}) \mathrm{ACN}$ to dehydrate the gel pieces. Vortex for $5 \mathrm{~min}$ and centrifuge at $16,000 \times g$ for $30 \mathrm{sec}$. Repeat this step

- Evaporate the solvents from the gel pieces in a vacuum concentrator centrifuge (approximately $20 \mathrm{~min}$ )

- Add $10 \mu \mathrm{L}$ of trypsin $(10 \mathrm{ng} / \mu \mathrm{L})$ to the dried gel pieces and incubate for a few min to allow rehydration

- Add $25 \mu \mathrm{L} 25 \mathrm{mM}$ ABC (or sufficient volume to cover the gel pieces), vortex for $5 \mathrm{~min}$, centrifuge at $16,000 \times g$ for $30 \mathrm{sec}$ and incubate at $37^{\circ} \mathrm{C}$ overnight in a wet chamber

- Centrifuge at $16,000 \times g$ for $30 \mathrm{sec}$. Add $10 \mu \mathrm{L}$ water, vortex for $10 \mathrm{~min}$ and centrifuge at $16,000 \times g$ for $30 \mathrm{sec}$

- Transfer the tryptic peptides (aqueous extraction) into a new reaction tube

- Add $30 \mu \mathrm{L}$ (or enough to cover) of 50\% (v/v) ACN/5\% (v/v) FA to the gel pieces, vortex for $10 \mathrm{~min}$ and centrifuge at $16,000 \times g$ for $30 \mathrm{sec}$. Combine the supernatants of this and the previous step. Repeat this step once more

- Add $10 \mu \mathrm{L} \mathrm{100 \%} \mathrm{(v/v)} \mathrm{ACN} \mathrm{to} \mathrm{the} \mathrm{gel} \mathrm{pieces,} \mathrm{vortex} \mathrm{for} 5$ min and centrifuge at $16,000 \times g$ for $30 \mathrm{sec}$. Combine with previous extractions

- Centrifuge the tryptic peptide mix at $16,000 \times g$ for $30 \mathrm{sec}$ and evaporate solvents in a vacuum concentrator centrifuge (approximately 2 hrs)

- Re-suspend the peptides $50 \mu \mathrm{L} 5 \%$ ACN/0.1\% FA to obtain a final concentration of $1 \mu \mathrm{g} / \mu \mathrm{L}$

- Aliquot and store tryptic peptides at $-80^{\circ} \mathrm{C}$

\section{Compared to the original protocol the following changes were made:}

- 4\% SDS and 0.1 M DTT were added to the lysis buffer

- The lysis of yeast cells was performed using Fast Prep at $6.5 \mathrm{Ms}^{-1}, 20 \mathrm{sec}$. This step was repeated 3 times with a $5 \mathrm{~min}$ interval on ice in between runs

- An incubation at $95^{\circ} \mathrm{C}$ for 5 min was performed to achieve a complete lysis of cells

- Sonication was performed to reduce viscosity of the sample

Protocol 2 : In-gel digestion in combination with protein extraction in ammonium bicarbonate (ABC)

(Adapted from Kaiser, P, Meierhofer, D, Wang, X, Huang, L. Tandem affinity purification combined with mass spectrometry to identify components of protein complexes. Methods Mol. Biol. 2008, 439: 309-326)
Materials

\section{Solutions and reagents}

Lysis buffer: $0.05 \mathrm{M}$ Ammonium bicarbonate (Fluka Cat. No. 40867-50G-F) in water

ABC: 0.05 M Ammonium bicarbonate (Fluka Cat. No. 40867-50G-F) in water

DTT: 0.09 M Dithiothreitol (Melford Cat No. MB1015)

IAA: 0.1 M Iodoacetamide (Sigma Cat. No. I1149-5G) in ABC

Sequencing Grade Modified Trypsin: Stock $0.2 \mu \mathrm{g} / \mu \mathrm{L}$ (Promega Cat. No. V5111)

UPLC/MS water

FA: Formic acid

ACN: Acetonitrile

$30 \%$ Acrylamide/0.8\% Bis-acrylamide (Protogel, Geneflow Limited Cat. No. EC-890)

$10 \%$ ammonium persulfate (APS, Sigma Cat. No. A3678-25G)

$10 \%$ Sodium dodecyl sulfate (SDS, Melford Cat. No. S1030)

$1.5 \mathrm{M}$ Tris/ $\mathrm{HCl} \mathrm{pH} 8.8$

$0.5 \mathrm{M}$ Tris/ $\mathrm{HCl}$ pH 6.8

BCA Protein assay kit (Pierce Cat. No. 23225)

\section{Equipment}

Protein Gel Casting Stand (BioRad)

Acid-washed glass beads (Sigma G8772-500G)

Protein LoBind tubes (Eppendorf Cat. No. 0030 108.094)

Fast Prep-24 instrument (MP Biomedicals)

Refrigerated bench top centrifuge

Spectrophotometer

Wet chamber

Vacuum concentrator centrifuge

Method

\section{Sample lysis}

- Add 200 $\pm 10 \mathrm{mg}$ glass beads and $200 \mu \mathrm{L}$ lysis buffer to $30 \mathrm{mg}$ cells (wet weight, equaling $10 \mathrm{OD}_{600}$ units of yeast cells)

- Vibrate the cell suspension in a Fast Prep-24 instrument $\left(4^{\circ} \mathrm{C}\right.$, settings: $6.5 \mathrm{Ms}^{-1}, 20 \mathrm{sec}$ ). Repeat this step 2 times with a $5 \mathrm{~min}$ interval, keep samples on ice between intervals

- Centrifuge at $16,000 \times g$ for $5 \mathrm{~min}$

- Transfer the supernatant to a new reaction tube 
- Centrifuge at $16,000 \times g$ for $5 \mathrm{~min}$

- Transfer the supernatant to a new reaction tube

\section{Protein quantification}

- Use BCA assay to determine the protein concentration according to the manufacturer's instructions

\section{Sample processing}

\subsection{Protein separation by SDS-PAGE}

- Cast separating (15\% acrylamid/bisacrylamide) and stacking gels $(4 \%)$ according to Laemmli (Laemmli, UK. Cleavage of structural proteins during the assembly of the head of bacteriophage T4. Nature. 1970, 227, 680-685)

- Add SDS-PAGE loading buffer to a lysate aliquot containing 50 $\mu \mathrm{g}$ protein and incubate at $95^{\circ} \mathrm{C}$ for $5 \mathrm{~min}$ to denature proteins

- Perform electrophoresis for $20 \mathrm{~min}$ at $80 \mathrm{~V}$ and for $45 \mathrm{~min}$ at $20 \mathrm{~V}$ (constant voltage)

- Excise the sample from the gel

\subsection{Excision and in-gel digestion of protein bands}

- Cut the gel slice into small pieces $(1 \mathrm{~mm})$ and place into a new reaction tube

- Add $100 \mu \mathrm{L}$ (or enough to cover) $25 \mathrm{mM} \mathrm{ABC/50 \%} \mathrm{(v/v)} \mathrm{ACN}$ and vortex for $10 \mathrm{~min}$

- Centrifuge at $16,000 \times g$ for $30 \mathrm{sec}$ and remove the supernatant using a gel-loading micropipette tip. Repeat this step 2 or 3 times

- Evaporate the solvents in a vacuum concentrator centrifuge (approximately $20 \mathrm{~min}$ )

- Add $50 \mu \mathrm{L}$ (or enough to cover) $10 \mathrm{mM}$ DTT in $25 \mathrm{mM} \mathrm{ABC}$ to the dried gel pieces

- Vortex and centrifuge at $16,000 \times g$ for $30 \mathrm{sec}$

- Incubate with the reductive solution at $56^{\circ} \mathrm{C}$ for $1 \mathrm{~h}$

- Remove the supernatant and add $50 \mu \mathrm{L}$ (or enough to cover) $50 \mathrm{mM}$ IAA to the gel pieces. Vortex and centrifuge at $16,000 \times g$ for $30 \mathrm{sec}$

- Incubate with the alkylating solution in the dark for $30 \mathrm{~min}$ at room temperature, with occasional vortexing. Centrifuge at $16,000 \times g$ for $30 \mathrm{sec}$

- Remove the supernatant. Add $\sim 100 \mu \mathrm{L} 25 \mathrm{mM}$ ABC to the gel pieces. Vortex for $5 \mathrm{~min}$ and centrifuge at $16,000 \times g$ for $30 \mathrm{sec}$

- Remove the supernatant and add $\sim 100 \mu \mathrm{L}$ (or enough to cover) $25 \mathrm{mM}$ ABC/50\% (v/v) ACN to dehydrate the gel pieces. Vortex for $5 \mathrm{~min}$ and centrifuge at $16,000 \times g$ for $30 \mathrm{sec}$. Repeat this step

- Evaporate the solvents from the gel pieces in a vacuum concentrator centrifuge (approximately $20 \mathrm{~min}$ )

- Add $10 \mu \mathrm{L}$ of trypsin $(10 \mathrm{ng} / \mu \mathrm{L})$ to the dried gel pieces and incubate for a few min to allow rehydration
- Add $25 \mu \mathrm{L} 25 \mathrm{mM}$ ABC (or sufficient volume to cover the gel pieces), vortex for $5 \mathrm{~min}$, centrifuge at $16,000 \times g$ for $30 \mathrm{sec}$ and incubate at $37^{\circ} \mathrm{C}$ overnight in a wet chamber

- Centrifuge at $16,000 \times g$ for $30 \mathrm{sec}$. Add $10 \mu \mathrm{L}$ water, vortex for $10 \mathrm{~min}$ and centrifuge at $16,000 \times$ for $30 \mathrm{sec}$

- Transfer the tryptic peptides (aqueous extraction) into a new reaction tube

- Add $30 \mu \mathrm{L}$ (or enough to cover) of $50 \%$ (v/v) ACN/5\% (v/v) FA to the gel pieces, vortex for $10 \mathrm{~min}$ and centrifuge at 16,000 $\times g$ for $30 \mathrm{sec}$. Combine the supernatants of this and the previous step. Repeat this step once more

- Add $10 \mu \mathrm{L} 100 \%$ (v/v) ACN to the gel pieces, vortex for $5 \mathrm{~min}$ and centrifuge at $16,000 \times g$ for $30 \mathrm{sec}$. Combine with previous extractions

- Centrifuge the tryptic peptide mix at $16,000 \times g$ for $30 \mathrm{sec}$ and evaporate solvents in a vacuum concentrator centrifuge (approximately $2 \mathrm{~h}$ )

- Re-suspend the peptides $50 \mu \mathrm{L} 5 \%$ ACN/0.1\% FA to obtain a final concentration of $1 \mu \mathrm{g} / \mu \mathrm{L}$

- Aliquot the flow-through and store tryptic peptides at $-80^{\circ} \mathrm{C}$

\section{Compared to the original protocol the following changes were} made:

- Cell lysis and protein extraction was performed in $50 \mathrm{mM} \mathrm{ABC}$

- The lysis of yeast cells was performed on a Fast Prep instrument

Protocol 3: Filter-aided sample preparation (FASP) (Adapted from Wisniewski, JR, Zougman, A, Nagaraj, N, Mann, M. Universal sample preparation method for proteome analysis. Nat. Methods 2009, 6: 359-363)

\section{Materials}

\section{Solutions and reagents}

Lysis buffer: SDT buffer (4\% SDS, $100 \mathrm{mM}$ Tris/HCl pH 7.6, $0.1 \mathrm{M}$ Dithiothreitol (DTT, Melford Cat No. MB1015)

UA: $8 \mathrm{M}$ urea in $0.1 \mathrm{M}$ Tris/ $\mathrm{HCl} \mathrm{pH} 8.5$

UB: $8 \mathrm{M}$ urea in $0.1 \mathrm{M}$ Tris/ $\mathrm{HCl} \mathrm{pH} 8$

IAA: 0.05 M Iodoacetamide (Sigma Cat. No. I1149-5G) in UA

Lys-C: Sequencing grade Endoproteinase Lys-C (Stock $0.1 \mu \mathrm{g} / \mu \mathrm{L}$; Promega Cat. No. V1071) in UB

Sequencing Grade Modified Trypsin: Stock $0.2 \mu \mathrm{g} / \mu \mathrm{L}$ (Promega Cat. No. V5111)

ABC: 0.05 M Ammonium bicarbonate (Fluka Cat. No. 40867-50G-F) in water

$0.5 \mathrm{M} \mathrm{NaCl}$

TFA: Trifluoroacetic acid (Sigma Cat. No. T6508) 
FA: Formic acid

ACN: Acetonitrile

BCA Protein assay kit (Pierce Cat. No. 23225)

\section{Equipment}

Acid-washed glass beads (Sigma Cat. No. G8772-500G)

Fast Prep-24 instrument (MP Biomedicals)

Amicon Ultra-0.5 Centrifugal Filter Unit with Ultracel-3 membrane (Millipore Cat. No. UFC500396)

Protein LoBind tubes (Eppendorf Cat. No. 0030 108.094)

Empore SPE Cartridges C18 (standard density), bed I.D. $7 \mathrm{~mm}$, volume $3 \mathrm{~mL}$ (Sigma Cat. No. 66872-U)

Ultrasonic tank (Langford Electronics Limited)

Refrigerated bench top centrifuge

Thermomixer (Eppendorf)

Spectrophotometer

Wet chamber

Vacuum concentrator centrifuge

Method

\section{Sample lysis}

- Add $200 \pm 10 \mathrm{mg}$ glass beads and $200 \mu \mathrm{l}$ lysis buffer to $30 \mathrm{mg}$ cells (wet weight, equaling $10 \mathrm{OD}_{600}$ units of yeast cells)

- Vibrate the cell suspension in a Fast Prep-24 instrument $\left(4^{\circ} \mathrm{C}\right.$, settings: $6.5 \mathrm{Ms}^{-1}, 20 \mathrm{sec}$ ). Repeat this step 2 times with a $5 \mathrm{~min}$ interval, keep samples on ice between intervals

- Centrifuge at $16,000 \times g$ for $1 \mathrm{~min}$ to sediment the cell debris

- Incubate for $3-5 \mathrm{~min}$ at $95^{\circ} \mathrm{C}$

- Centrifuge as above and transfer the supernatant to a new reaction tube

- Sonicate for $5 \mathrm{~min}$ in an ultrasonic tank to reduce viscosity

\section{Protein quantification}

- Use BCA assay to determine the protein concentration according to the manufacturer's instructions

\section{Sample processing}

\subsection{On-filter digestion}

- Apply $30 \mu \mathrm{L}$ protein sample to the filter unit and add $200 \mu \mathrm{L}$ UA

- Centrifuge at $14,000 \times g$ for $40 \mathrm{~min}$

- Apply $200 \mu \mathrm{L}$ UA to the filter unit and centrifuge at $14,000 \times g$ for $40 \mathrm{~min}$

- Incubate for $5 \mathrm{~min}$ in dark
- Centrifuge $14,000 \times g$ for $30 \mathrm{~min}$

- Apply $100 \mu \mathrm{L}$ UB to the filter unit and centrifuge $14,000 \times g$ for $40 \mathrm{~min}$. Repeat this step two more times

- Apply $40 \mu \mathrm{L}$ UB with Lys-C (enzyme to protein ratio 1:50) to the filter unit and mix at $600 \mathrm{rpm}$ for $1 \mathrm{~min}$ at RT

- Incubate the units in wet chamber at $37^{\circ} \mathrm{C}$ overnight

- Transfer the filter unit to a new collection tube

- Apply $120 \mu \mathrm{L}$ ABC with trypsin (enzyme to protein ratio 1:100) to the filter unit and mix at $600 \mathrm{rpm}$ for $1 \mathrm{~min}$ at RT

- Incubate the filter unit at RT for $4 \mathrm{hrs}$

- Centrifuge at $14,000 \times g$ for $40 \mathrm{~min}$

- Apply $50 \mu \mathrm{L} 0.5 \mathrm{M} \mathrm{NaCl}$ to the filter unit and centrifuge at $14,000 \times g$ for $20 \mathrm{~min}$

- Add TFA to reach a final concentration of $0.5 \%$ and remove salts from the filtrate

\subsection{Desalting of peptides}

- Place a 3 ml MILI-SPE Extraction disk cartridge (C18-SD) in a $15 \mathrm{ml}$ conical tube

- Add $1 \mathrm{ml}$ TFA and centrifuge at $1,500 \times g$ for $1 \mathrm{~min}$

- Add $0.5 \mathrm{ml}$ of $0.1 \% \mathrm{TFA}, 70 \% \mathrm{ACN}$ in water and centrifuge at $1,500 \times g$ for $1 \mathrm{~min}$

- Add $0.5 \mathrm{ml}$ of $0.1 \%$ TFA in water and centrifuge at $1,500 \times g$ for $1 \mathrm{~min}$

- Load the filtrate and centrifuge at $150 \times g$ for $3 \mathrm{~min}$

- Add $0.5 \mathrm{ml}$ of $0.1 \%$ TFA in water and centrifuge at $150 \times g$ for $3 \mathrm{~min}$

- Transfer the cartridge to a new tube, add $0.5 \mathrm{ml}$ of $70 \% \mathrm{ACN}$ in water and centrifuge at $150 \times g$ for $3 \mathrm{~min}$

- Collect the flow-through that contains the desalted peptides

- Remove solvents in vacuum concentrator centrifuge and re-suspend in $30 \mu \mathrm{L} \mathrm{5 \%} \mathrm{ACN/0.1 \%} \mathrm{FA}$

- Aliquot and store tryptic peptides at $-80^{\circ} \mathrm{C}$

Compared to the original protocol the following changes were made:

- Yeast cells lysis was perfomed using a Fast Prep-24 instrument

- Amicon Ultra-0.5 Centrifugal Filter Unit with Ultracel-3 membrane was used (Millipore, Cat. No 42407)

\section{Protocol 4: eFASP}

(Adapted from Shevchenko,G, Musunuri, S, Wetterhall, M, Bergquist, J. Comparison of extraction methods for the comprehensive analysis of mouse brain proteome using shotgun-based mass spectrometry. J. Proteome Res. 2012, 11, 2441-2451) 
Materials

\section{Solutions and reagents}

Lysis buffer: 1\% SDS, $10 \mathrm{mM}$ Tris/HCl pH 7.4, $0.15 \mathrm{M} \mathrm{NaCl}$, 1 mM EDTA in PBS

TBP: tri-n-butylphosphate (Fluka Cat. No. 90820-100ML)

Acetone

Methanol

ACN: Acetonitrile

Digestion buffer: 1\% n-octyl-beta-D-glucopyranoside (nOGP, Sigma Cat. No. O8001) in 50:50 ACN/8 M urea

Complete EDTA-free Protease inhibitor Cocktail tablets Roche Cat. No. 11873580001). Dissolve one tablet in $1 \mathrm{~mL}$ water, to achieve a $50 \mathrm{x}$ stock solution

0.09 M Dithiothreitol (DTT, Melford Cat No. MB1015)

0.1 M Iodoacetamide (IAA, Sigma Cat. No. I1149-5G)

Sequencing Grade Modified Trypsin: Stock $0.2 \mu \mathrm{g} / \mu \mathrm{L}$ (Promega Cat. No. V5111)

ABC: 0.05 M Ammonium bicarbonate (Fluka Cat. No. 40867-50G-F) in water

\section{UPLC/MS grade water}

FA: Formic acid

Acetic acid

BCA Protein assay kit (Pierce Cat. No. 23225)

\section{Equipment}

Glass Dounce homogenizer (Thomas Scientific Cat. No. 3432N75)

Amicon Ultra-0.5 Centrifugal Filter Unit with Ultracel-3 membrane (Millipore Cat. No. UFC500396)

Protein LoBind tubes (Eppendorf Cat. No. 0030 108.094)

Refrigerated bench top centrifuge

Spectrophotometer

Vacuum concentrator centrifuge

Method

1 Sample lysis

- Add $200 \mu \mathrm{L}$ lysis buffer to $30 \mathrm{mg}$ cells (wet weight, equaling $10 \mathrm{OD}_{600}$ units of yeast cells)

- Lyse cells in a glass Dounce homogenizer for $1 \mathrm{~min}$

- Add $4 \mu \mathrm{L}$ protease inhibitor solution

- Incubate the sample at $4^{\circ} \mathrm{C}$ for $1 \mathrm{~h}$ with mild agitation

- Centrifuge for $30 \mathrm{~min}$ at $10,000 \times g, 4^{\circ} \mathrm{C}$

- Transfer supernatant to a new reaction tube

\section{Sample Processing}

2.1 Delipidation and protein precipitation

- Mix $90 \mu \mathrm{L}$ cell extract with $1.26 \mathrm{~mL}$ ice-cold TBP/acetone/ methanol mix (1:12:1)

- Incubate at $4^{\circ} \mathrm{C}$ for $90 \mathrm{~min}$

- Centrifuge at $2,800 \times g$ at $4^{\circ} \mathrm{C}$ for $15 \mathrm{~min}$

- Re-suspend the pellet in $1 \mathrm{ml}$ TBP

- Centrifuge at $16,000 \times g$ at $4^{\circ} \mathrm{C}$ for $15 \mathrm{~min}$

- Re-suspend the pellet in $1 \mathrm{ml}$ acetone

- Centrifuge at $16,000 \times g$ at $4^{\circ} \mathrm{C}$ for $15 \mathrm{~min}$

- Re-suspend the pellet in $1 \mathrm{ml}$ methanol

- Centrifuge at $16,000 \times g$ at $4^{\circ} \mathrm{C}$ for $15 \mathrm{~min}$

- Evaporate solvents by incubating the sample at room temperature (RT) for $15 \mathrm{~min}$

- Re-suspend the pellet in $100 \mu \mathrm{L}$ digestion buffer

\subsection{Protein quantification}

- Use BCA assay to determine the protein concentration according to the manufacturer's instructions

\subsection{On-filter digestion}

- Add $36 \mu \mathrm{L}$ of $45 \mathrm{mM}$ DTT to $30 \mu \mathrm{g}$ protein (in $90 \mu \mathrm{L}$ ) and incubate at $50^{\circ} \mathrm{C}$ for $15 \mathrm{~min}$

- Incubate samples at RT for $15 \mathrm{~min}$

- Add $36 \mu \mathrm{L}$ of $100 \mathrm{mM}$ IAA and incubate at room temperature for $15 \mathrm{~min}$ in dark

- Apply $250 \mu \mathrm{L} 50 \% \mathrm{ACN}$ to the filter unit and centrifuge at $14,000 \times g$ for $15 \mathrm{~min}$

- Apply $500 \mu \mathrm{L}$ water to the filter unit and centrifuge at 14,000 $\times g$ for 20 min

- Apply the protein sample to the filter unit and centrifuge for 15 $\min$ at $14,000 \times g$ to remove salts and detergents

- Add $100 \mu \mathrm{L} 2 \%$ ACN in $50 \mathrm{mM} \mathrm{ABC}$ and centrifuge at 14,000 $\times g$ for $10 \mathrm{~min}$

- Add $100 \mu \mathrm{L}$ 50:50 ACN/50 mM ABC and $100 \mu \mathrm{L} 50 \mathrm{mM}$ $\mathrm{ABC}$, centrifuge at $14,000 \mathrm{~g}$ for $10 \mathrm{~min}$

- Add $100 \mu \mathrm{L} 50 \mathrm{mM}$ ABC containing trypsin to achieve an enzyme to protein ratio of 1:40

- Incubate at $37^{\circ} \mathrm{C}$ overnight

- Centrifuge at $14,000 \times g$ for $20 \mathrm{~min}$ and transfer the filtrate to a new reaction tube

- Add $100 \mu \mathrm{L} 50 \%$ ACN/1\% acetic acid to the filter and centrifuge for $10 \mathrm{~min}$ at $14,000 \times g$

- Combine with the previous filtrate 
- Evaporate the solvents using a vacuum concentrator centrifuge (approximately $3 \mathrm{hrs}$ )

- Re-suspend the tryptic peptides in 5\% ACN/0.1\% FA to obtain a final concentration of $1 \mu \mathrm{g} / \mu \mathrm{l}$

- Aliquot and store tryptic peptides at $-80^{\circ} \mathrm{C}$

Compared to the original protocol the following changes were made:

- $90 \mu \mathrm{l}$ of cell extract was subjected to delipidation

- $30 \mu \mathrm{g}$ of protein were used for tryptic digestion

\section{Protocol 5 : RapiGest}

(Waters (UK), RapiGest-including version of a protocol based on der Haar, T. Optimized protein extraction for quantitative proteomics of yeasts. PLoS One 2007, 2: e1078)

\section{Materials}

\section{Solutions and reagents}

Lysis buffer: $0.1 \mathrm{M} \mathrm{NaOH}, 0.05 \mathrm{M}$ EDTA, 2\% SDS, 2\% $\beta$-mercaptoethanol

ABC: 0.05 M Ammonium bicarbonate (Fluka Cat. No. 40867-50GF) in water

DTT: 0.05 M Dithiothreitol (Melford Cat No. MB1015)

IAA: 0.1 M Iodoacetamide (Sigma Cat. No. I1149-5G) in ABC

Sequencing Grade Modified Trypsin: Stock $0.2 \mu \mathrm{g} / \mu \mathrm{L}$ (Promega Cat. No. V5111)

Rapigest SF Surfactant: Stock 0.2\% in ABC (Waters Cat. No. 186002123)

Acetonitrile (ACN)

Acetic acid

Trichloroacetic acid (TCA)

Acetone

water, UPLC/MS grade

BCA Protein assay kit (Pierce Cat. No. 23225)

\section{Equipment}

Protein LoBind tubes (Eppendorf Cat. No. 0030 108.094)

Refrigerated bench top centrifuge

Ultrasonic tank (Langford Electronics Limited)

Thermomixer (Eppendorf)

Spectrophotometer

Wet chamber

Vacuum concentrator centrifuge
Method

\section{Sample lysis}

- Add $200 \mu \mathrm{L}$ lysis buffer per $30 \mathrm{mg}$ cells (wet weight, equaling $10 \mathrm{OD}_{600}$ units of yeast cells)

- Incubate for $10 \mathrm{~min}$ at $90^{\circ} \mathrm{C}$

- Add $5 \mu \mathrm{L} 4 \mathrm{M}$ acetic acid and vortex for $30 \mathrm{sec}$

- Incubate for $10 \mathrm{~min}$ at $90^{\circ} \mathrm{C}$

- Centrifuge at $16,000 \times g$ for $5 \mathrm{~min}$

- Transfer the supernatant to a new reaction tube

\section{Protein precipitation}

- Add $205 \mu \mathrm{L} 20 \%$ TCA to reach a final concentration of $10 \%$

- Incubate for $2-3 \mathrm{hrs}$ at $-80^{\circ} \mathrm{C}$ to favor protein precipitation

- Centrifuge at $20,000 \times g$ for $30 \mathrm{~min}$ at $4^{\circ} \mathrm{C}$

- Re-suspend the pellet in $1 \mathrm{ml} 80 \%$ acetone, solubilize by incubating for 5 min in an ultrasonic tank. Repeat this step until suspension is homogenous

- Incubate at $4^{\circ} \mathrm{C}$ for $1 \mathrm{~h}$

- Centrifuge at $20,000 \times g$ for $30 \mathrm{~min}$ at $4^{\circ} \mathrm{C}$

- Re-suspend the pellet in $1 \mathrm{ml} 80 \%$ acetone by sonicating for $5 \mathrm{~min}$. Repeat this step until suspension is homogenous (Optional: store at $-80^{\circ} \mathrm{C}$ overnight)

- Centrifuge at $20,000 \times g$ for $30 \mathrm{~min}, 4^{\circ} \mathrm{C}$

- Dry the pellet at room temperature (RT) for 10-30 min

\section{Solubilisation and Protein quantification}

- Add $100 \mu \mathrm{L} 0.2 \%$ Rapigest in $50 \mathrm{mM}$ ABC to the pellet

- Incubate for $10 \mathrm{~min}$ at $40^{\circ} \mathrm{C}$ at $400 \mathrm{rpm}$ in a thermoshaker (keep tubes open to let acetone evaporate)

- Sonicate to dissolve the pellet using the ultrasonic tank $(5 \times 90 \mathrm{sec}$ pulse, $30 \mathrm{sec}$ pause on ice). Repeat this step until precipitate is fully dissolved and solution appears clear

- (Optional: if proteins remain insoluble, add $50 \mu \mathrm{L} 0.2 \%$ Rapigest in $50 \mathrm{mM} \mathrm{ABC}$ to the sample and repeat sonication)

\section{Protein quantification}

- Use BCA assay to determine the protein concentration according to the manufacturer's instructions

\section{Sample processing}

- Transfer $50 \mu \mathrm{g}$ protein to a new reaction tube, fill up with $50 \mathrm{mM}$ $\mathrm{ABC}$ to reach a total volume of $22.5 \mu \mathrm{L}$

- Add $2.5 \mu \mathrm{L} 50 \mathrm{mM}$ DTT in $50 \mathrm{mM}$ ABC to reach a final concentration of $4.5 \mathrm{mM}$. Incubate at $60^{\circ} \mathrm{C}$ for $30 \mathrm{~min}$ 
- Add $2.8 \mu \mathrm{L} 100 \mathrm{mM}$ IAA in $50 \mathrm{mM} \mathrm{ABC}$ and $0.2 \mu \mathrm{L} 50 \mathrm{mM}$ $\mathrm{ABC}$ to reach a final concentration of $10 \mathrm{mM}$

- Incubate in dark for $30 \mathrm{~min}$ at RT

- Add 6.25 $\mu \mathrm{L}$ trypsin (enzyme to protein ratio 1:40)

- incubate $2 \mathrm{~h}$ at $37^{\circ} \mathrm{C}$

- Add 6.25 $\mu \mathrm{L}$ trypsin (enzyme to protein ratio 1:40)

- Incubate at $37^{\circ} \mathrm{C}$ overnight

- Add $10 \%$ TFA to reach a final concentration of $0.5 \%$

- Incubate at $37^{\circ} \mathrm{C}$ for $1 \mathrm{~h}$

- Centrifuge at $20,000 \times g$ for $10 \mathrm{~min}$ at $4^{\circ} \mathrm{C}$

- Transfer the supernatant containing the tryptic peptides to a new reaction tube without disturbing the pellet

- Add ACN to reach a final concentration of $5 \%$

- Centrifuge at $20,000 \times g$ for $3 \mathrm{~min}$

- Transfer supernatant to a new reaction tube

- Centrifuge at $20,000 \times g$ for $10 \mathrm{~min}$

- Adjust the volume with UPLC/MS water to obtain a final protein concentration of $1 \mu \mathrm{g} / \mu \mathrm{L}$

- Aliquot and store tryptic peptides at $-80^{\circ} \mathrm{C}$

\section{Compared to the original protocol the following changes were} made:

- Protein pellets were re-suspended by sonication using Rapigest as surfactant

- Protein precipitation was performed using 20\% TCA

- Protein pellets were washed twice using $80 \%$ acetone

- Trypsin was added in two sequential steps to reach a final enzyme to protein ratio 1:20

\section{Protocol 6: RapidACN}

(Bluemlein, K, Ralser, M. Monitoring protein expression in wholecell extracts by targeted label- and standard-free LC-MS/MS. Nat. Protoc. 2011, 6: 859-869)

\section{Materials}

\section{Solutions and reagents}

ABC: 0.05 M Ammonium bicarbonate (Fluka Cat. No. 40867-50G-F) in water

DTT: 0.09 M Dithiothreitol (Melford Cat No. MB1015)

IAA: 0.1 M Iodoacetamide (Sigma Cat. No. I1149-5G) in ABC

TCEP: 0.1 M tris(2-carboxyethyl)phosphine (Sigma Cat. No. C4706-2G)

Sequencing Grade Modified Trypsin: Stock $0.2 \mu \mathrm{g} / \mu \mathrm{L}$ (Promega Cat. No. V5111)
UPLC/MS water

FA: Formic acid

ACN: Acetonitrile

BCA Protein assay kit (Pierce Cat. No. 23225)

\section{Equipment}

Acid-washed glass beads (Sigma G8772-500G)

Amicon Ultra-0.5 Centrifugal Filter Unit with Ultracel-3 membrane (Millipore Cat. No. UFC500396)

Protein LoBind tubes (Eppendorf Cat. No. 0030 108.094)

Fast Prep-24 instrument (MP Biomedicals)

Refrigerated bench top centrifuge

Spectrophotometer

Wet chamber

Vacuum concentrator centrifuge

Method

\section{Sample lysis}

- Add 200 $\pm 10 \mathrm{mg}$ beads to $30 \mathrm{mg}$ cells (wet weight, equaling 10 $\mathrm{OD}_{600}$ units of yeast cells)

- add $200 \mu \mathrm{L} 50 \mathrm{mM}$ ABC

- Vibrate the cell suspension in a Fast Prep-24 instrument $\left(4^{\circ} \mathrm{C}\right.$, settings: $6.5 \mathrm{Ms}^{-1}, 20 \mathrm{sec}$ ). Repeat this step 2 times with a $5 \mathrm{~min}$ interval, keep samples on ice between cycles

- Centrifuge $16,000 \times g$ for $5 \mathrm{~min}$

- Transfer supernatant to a new reaction tube

- Centrifuge at $16,000 \times g$ for $5 \mathrm{~min}$

- Transfer the supernatant to a new reaction tube

\section{Protein quantification}

- Use BCA assay to determine the protein concentration according to the manufacturer's instructions

\section{Sample processing}

- Dilute the protein samples with $50 \mathrm{mM} \mathrm{ABC}$ to reach a final concentration of $2 \mu \mathrm{g} / \mu \mathrm{L}$

- Add $25 \mu \mathrm{L} 100 \%$ ACN to $25 \mu \mathrm{L}$ protein sample (corresponding to $50 \mu \mathrm{g}$ total protein)

- Vortex thoroughly

- Centrifuge at $16,000 \times g$ for $1 \mathrm{~min}$

- Incubate at $37^{\circ} \mathrm{C}$ for $15 \mathrm{~min}$

- Add $5 \mu \mathrm{L} 45$ mM DTT/20 mM TCEP solution 
- Incubate at $37^{\circ} \mathrm{C}$ for $30 \mathrm{~min}$

- Add $5 \mu \mathrm{L}$ IAA and incubate in the dark at room temperature for $30 \mathrm{~min}$

- Centrifuge at $16,000 \times g$ for 1 min

- Add 5.5 $\mu \mathrm{L}$ DTT to quench any residual IAA

- Add 134.5 $\mu \mathrm{L}$ UPLC-grade water

- Vortex and centrifuge at $16,000 \times g$ for $1 \mathrm{~min}$

- Add 6.25 $\mu \mathrm{L}$ trypsin (enzyme to protein ratio 1:40)

- Incubate at $37^{\circ} \mathrm{C}$ for $2 \mathrm{hrs}$

- Centrifuge at $16,000 \times g$ for 1 min and add $6.25 \mu \mathrm{L}$ trypsin (enzyme to protein ratio 1:40)

- Incubate at $37^{\circ} \mathrm{C}$ overnight in a wet chamber

- Centrifuge at $16,000 \times g$ for $1 \mathrm{~min}$
- Dry the sample using a vacuum concentrator centrifuge (approximately $2 \mathrm{hrs}$ )

- Re-suspend in $50 \mu \mathrm{L} 5 \% \mathrm{ACN} / 0.1 \%$ formic acid

- Add $2 \mu \mathrm{L} 10 \% \mathrm{FA}$, vortex and centrifuge at $16,000 \times g$ for 1 $\min$

- Incubate at room temperature for $5 \mathrm{~min}$

- Apply sample to filter unit and centrifuge at $12,000 \times g$ for 20 $\min$

- Aliquot the flow-through and store tryptic peptides at $-80^{\circ} \mathrm{C}$

Compared to the original protocol the following changes were made:

- Trypsin was added at a ratio protein:enzyme ratio of 1:20

- Trypsin was added in two sequential steps 
1. Aebersold R, Mann M: Mass spectrometry-based proteomics. Nature. 2003; 422(6928): 198-207.

PubMed Abstract | Publisher Full Text

2. Thakur SS, Geiger T, Chatterjee B, et al:: Deep and highly sensitive proteome coverage by LC-MS/MS without prefractionation. Mol Cell proteomics. 2011; 10(8): M110.003699.

PubMed Abstract | Publisher Full Text | Free Full Text

3. Kocher T, Pichler P, Swart R, et al: Analysis of protein mixtures from whole-cell extracts by single-run nanoLC-MS/MS using ultralong gradients. Nat Protoc. 2012; 7(5): 882-890. PubMed Abstract | Publisher Full Text

4. Ong SE, Mann M: Mass spectrometry-based proteomics turns quantitative. Nat Chem Biol. 2005; 1(5): 252-62. PubMed Abstract | Publisher Full Text

5. Tao WA, Aebersold R: Advances in quantitative proteomics via stable isotope tagging and mass spectrometry. Curr Opin Biotechnol. 2003; 14(1): 110-118. PubMed Abstract | Publisher Full Text

6. Anderson L, Hunter CL: Quantitative mass spectrometric multiple reaction monitoring assays for major plasma proteins. Mol Cell Proteomics. 2006; 5(4): 573-88.

PubMed Abstract | Publisher Full Tex

7. Wolen RL: The Application of Stable Isotopes to Studies of Drug Bioavailability and Bioequivalence. J Clin Pharmacol. 1986; 26(6): 419-424. PubMed Abstract | Publisher Full Text

8. Ross PL, Huang YN, Marchese JN, et al:: Multiplexed protein quantitation in Saccharomyces cerevisiae using amine-reactive isobaric tagging reagents. Mol Cell proteomics MCP. 2004; 3(12): 1154-1169.

PubMed Abstract | Publisher Full Text

9. Bluemlein $\mathrm{K}$, Ralser M: Monitoring protein expression in whole-cell extracts by targeted label- and standard-free LC-MS/MS. Nat Protoc. 2011; 6(6): 859-69. PubMed Abstract | Publisher Full Text

10. Wang G, Wu WW, Zeng W, et al.: Label-free protein quantification using LCcoupled ion trap or FT mass spectrometry: Reproducibility, linearity, and application with complex proteomes. J Proteome Res. 2006; 5(5): 1214-1223. PubMed Abstract | Publisher Full Text

11. Silva JC, Gorenstein MV, Li GZ, et al:: Absolute quantification of proteins by LCMSE: a virtue of parallel MS acquisition. Mol Cell proteomics. 2006; $\mathbf{5}(1)$ : 144-156.

PubMed Abstract | Publisher Full Text

12. Grossmann J, Roschitzki B, Panse $C$, et al: Implementation and evaluation of relative and absolute quantification in shotgun proteomics with label-free methods. J Proteomics. 2010; 73(9): 1740-1746. PubMed Abstract | Publisher Full Tex

13. Griffin NM, Yu J, Long F, et al.: Label-free, normalized quantification of complex mass spectrometry data for proteomic analysis. Nat Biotechnol. 2010; 28(1): 83-9. PubMed Abstract | Publisher Full Text | Free Full Text

14. Zhu W, Smith JW, Huang CM: Mass spectrometry-based label-free quantitative proteomics. J Biomed Biotechnol. 2010; 2010: 840518. PubMed Abstract | Publisher Full Text | Free Full Text

15. Krüger A, Vowinckel J, Mülleder M, et al:: Tpo1-mediated spermine and spermidine export controls cell cycle delay and times antioxidant protein expression during the oxidative stress response. EMBO Rep. 2013; 14(12): 1113-1119. advance on

PubMed Abstract | Publisher Full Text

16. Bluemlein $\mathrm{K}$, Ralser M: Monitoring protein expression in whole-cell extracts by targeted label- and standard-free LC-MS/MS. Nat Protoc. 2011; 6(6): 859-869. PubMed Abstract | Publisher Full Text

17. Gillet LC, Navarro P, Tate S, et al:: Targeted data extraction of the MS/MS spectra generated by data independent acquisition: a new concept for consistent and accurate proteome analysis. Mol Cell Proteomics. 2012; 11(6) O111.016717.

PubMed Abstract | Publisher Full Text | Free Full Text

18. Ferreira-da-Silva F, Pereira PJ, Gales L, et al:: The crystal and solution structures of glyceraldehyde-3-phosphate dehydrogenase reveal different quaternary structures. J Biol Chem. 2006; 281(44): 33433-33440. PubMed Abstract | Publisher Full Text

19. Kaiser $\mathrm{P}$, Meierhofer $\mathrm{D}$, Wang $\mathrm{X}$, et al.: Tandem affinity purification combined with mass spectrometry to identify components of protein complexes. Methods Mol Biol. 2008; 439: 309-326. PubMed Abstract | Publisher Full Text | Free Full Text

20. Wisniewski JR, Zougman A, Nagaraj N, et al:: Universal sample preparation method for proteome analysis. Nat Methods. 2009; 6(5): 359-362. PubMed Abstract | Publisher Full Text

21. Shevchenko $G$, Musunuri S, Wetterhall $M$, et al: Comparison of extraction methods for the comprehensive analysis of mouse brain proteome using shotgun-based mass spectrometry. J Proteome Res. 2012; 11(4): 2441-51. PubMed Abstract | Publisher Full Text
22. Von der Haar T: Optimized protein extraction for quantitative proteomics of yeasts. PLoS One. 2007; 2(10): e1078. PubMed Abstract | Publisher Full Text | Free Full Text

23. Andrews GL, Simons BL, Young JB, et al.: Performance characteristics of a new hybrid quadrupole time-of-flight tandem mass spectrometer (TripleTOF 5600). Anal Chem. 2011: 83(13): 5442-5446. PubMed Abstract | Publisher Full Text | Free Full Text

24. Liu $Y$, Hüttenhain R, Surinova $S$, et al:: Quantitative Measurements of N-linked Glycoproteins in Human Plasma by SWATH-MS. Proteomics. 2013; 13(8): 1247-1256. PubMed Abstract | Publisher Full Text

25. Brachmann CB, Davies A, Cost GJ, et al:: Designer deletion strains derived from Saccharomyces cerevisiae S288C: a useful set of strains and plasmids for PCRmediated gene disruption and other applications. Yeast. 1998; 14(2): 115-132. PubMed Abstract | Publisher Full Text

26. Mulleder M, Capuano F, Pir P, et al.: A prototrophic deletion mutant collection for yeast metabolomics and systems biology. Nat Biotechnol. 2012; 30(12): 1176-1178.

PubMed Abstract | Publisher Full Text | Free Full Text

27. Kaiser P, Meierhofer D, Wang X, et al.: Genomics Protocols. Methods Mol Biol. 2008; 439: 1-16. Publisher Full Tex

28. Gillet LC, Navarro P, Tate S, et al: Targeted data extraction of the MS/MS spectra generated by data-independent acquisition: a new concept for consistent and accurate proteome analysis. Mol Cell Proteomics. 2012; 11(6): O111.016717.

PubMed Abstract | Publisher Full Text | Free Full Text

29. de Godoy LM, Olsen JV, Cox J: Comprehensive mass-spectrometry-based proteome quantification of haploid versus diploid yeast. Nature. 2008; 455(7217): 1251-1254

PubMed Abstract | Publisher Full Text

30. Cherry JM, Hong EL, Amundsen C, et al:: Saccharomyces Genome Database: the genomics resource of budding yeast. Nucleic Acids Res. 2012; 40(Database issue): D700-5. PubMed Abstract | Publisher Full Text | Free Full Text

31. MacLean B, Tomazela DM, Shulman N, et al.: Skyline: an open source document editor for creating and analyzing targeted proteomics experiments. Bioinformatics. 2010; 26(7): 966-968. PubMed Abstract | Publisher Full Text | Free Full Text

32. Wisniewski JR, Zougman A, Nagaraj N, et al.: Universal sample preparation method for proteome analysis. Nat Methods. 2009; 6(5): 359-362. PubMed Abstract | Publisher Full Text

33. Shevchenko G, Musunuri S, Wetterhall M, et al:: Comparison of extraction methods for the comprehensive analysis of mouse brain proteome using shotgun-based mass spectrometry. J Proteome Res. 2012; 11(4): 2441-51. PubMed Abstract | Publisher Full Text

34. Vasilj A, Gentzel M, Ueberham E, et al.: Tissue proteomics by one-dimensional gel electrophoresis combined with label-free protein quantification. $J$ Proteome Res. 2012; 11(7): 3680-3689. PubMed Abstract | Publisher Full Tex

35. Burnette WN: Western blotting: electrophoretic transfer of proteins from sodium dodecyl sulfate--polyacrylamide gels to unmodified nitrocellulose and radiographic detection with antibody and radioiodinated protein $\mathbf{A}$. Anal Biochem. 1981; 112(2): 195-203.

PubMed Abstract | Publisher Full Text

36. Piersma SR, Warmoes $\mathrm{MO}$, de Wit $\mathrm{M}$, et al:: Whole gel processing procedure for GeLC-MS/MS based proteomics. Proteome Sci. 2013; 11(1): 17 PubMed Abstract | Publisher Full Text | Free Full Text

37. Stover T, Amari J, Mazsaroff I, et al.: Novel characterization tool for Mab digestion-Technical note: RapiGest SF denaturant tool for improved trypsin digestion of monoclonal antibodies. Genet Eng News. 2003; 1: 1.

38. Goffeau A, Barrell BG, Bussey H, et al.: Life with 6000 genes. Science. 1996 274(5287): 546, 563-567. PubMed Abstract | Publisher Full Tex

39. Washburn M, Wolters D, Yates J: Large-scale analysis of the yeast proteome by multidimensional protein identification technology. Nat Biotechnol. 2001; 19(3): 242-247

PubMed Abstract | Publisher Full Tex

40. Picotti P, Lam H, Campbell D, et al.: A database of mass spectrometric assays for the yeast proteome. Nat Methods. 2008; 5(11): 913-914 PubMed Abstract | Publisher Full Text | Free Full Text

41. Picotti $\mathrm{P}$, Bodenmiller $\mathrm{B}$, Mueller $\mathrm{LN}$, et al:: Full dynamic range proteome analysis of S. cerevisiae by targeted proteomics. Cell. 2009; 138(4): 795-806. PubMed Abstract | Publisher Full Text | Free Full Text

42. Creasy DM, Cottrell JS: Error tolerant searching of uninterpreted tandem mass spectrometry data. Proteomics. 2002; 2(10): 1426-34. PubMed Abstract | Publisher Full Text 
43. Shilov IV, Seymour SL, Patel AA, et al:: The Paragon Algorithm, a next generation search engine that uses sequence temperature values and feature probabilities to identify peptides from tandem mass spectra. Mol Cell proteomics. 2007; 6(9): 1638-55.

PubMed Abstract | Publisher Full Text

44. Bernhardt O, Selevsek N, Gillet LC: Spectronaut: A fast and efficient algorithm for MRM-like processing of data independent acquisition (SWATH-MS) data. Biognosys.ch. Reference Source

45. Gerber SA, Rush J, Stemman O, et al:: Absolute quantification of proteins and phosphoproteins from cell lysates by tandem MS. Proc Natl Acad Sci U S A. 2003; 100(12): 6940-6945.

PubMed Abstract | Publisher Full Text | Free Full Text

46. Thompson A, Schäfer J, Kuhn K, et al: Tandem mass tags: a novel quantification strategy for comparative analysis of complex protein mixtures by MS/MS. Anal Chem. 2003; 75(8): 1895-1904.

PubMed Abstract | Publisher Full Text

47. Karp NA, Huber W, Sadowski PG, et al.: Addressing accuracy and precision issues in iTRAQ quantitation. Mol Cell Proteomics. 2010; 9(9): 1885-97. PubMed Abstract | Publisher Full Text | Free Full Text

48. Ow SY, Salim M, Noirel J, et al.: iTRAQ underestimation in simple and complex mixtures: the good, the bad and the ugly. J Proteome Res. 2009; 8(11): 5347-55. PubMed Abstract | Publisher Full Text

49. Ong SE, Blagoev B, Kratchmarova I, et al:: Stable isotope labeling by amino acids in cell culture, SILAC, as a simple and accurate approach to expression proteomics. Mol Cell Proteomics. 2002; 1(5): 376-386. PubMed Abstract | Publisher Full Text

50. Hebert AS, Merrill AE, Bailey DJ, et al:: Neutron-encoded mass signatures for multiplexed proteome quantification. Nat Methods. 2013; 10(4): 332-4. PubMed Abstract | Publisher Full Text | Free Full Text

51. Wu CC, MacCoss MJ, Howell KE, et al:: Metabolic labeling of mammalian organisms with stable isotopes for quantitative proteomic analysis. Anal Chem. 2004; 76(17): 4951-4959.

PubMed Abstract | Publisher Full Text

52. Piersma SR, Warmoes MO, de Wit M, et al.: Whole gel processing procedure for GeLC-MS/MS based proteomics. Proteome Sci. 2013; 11(1): 17. PubMed Abstract | Publisher Full Text | Free Full Text

53. Schirle M, Heurtier MA, Kuster B: Profiling core proteomes of human cell lines by one-dimensional PAGE and liquid chromatography-tandem mass spectrometry. Mol Cell Proteomics. 2003; 2(12): 1297-305. PubMed Abstract | Publisher Full Text

54. Glatter T, Ludwig C, Ahrne E, et al.: Large-scale quantitative assessment of different in-solution protein digestion protocols reveals superior cleavage efficiency of tandem Lys-C/trypsin proteolysis over trypsin digestion. $J$ Proteome Res. 2012; 11(11): 5145-56.

PubMed Abstract | Publisher Full Text

55. Wiśniewski JR, Zielinska DF, Mann M: Comparison of ultrafiltration units for proteomic and $\mathrm{N}$-glycoproteomic analysis by the filter-aided sample preparation method. Anal Biochem. 2011; 410(2): 307-9.

PubMed Abstract | Publisher Full Text 


\section{Open Peer Review}

\section{Current Peer Review Status:}

\section{Version 1}

Reviewer Report 04 March 2014

https://doi.org/10.5256/f1000research.3109.r3833

(C) 2014 Morrice $\mathbf{N}$. This is an open access peer review report distributed under the terms of the Creative Commons Attribution License, which permits unrestricted use, distribution, and reproduction in any medium, provided the original work is properly cited.

\section{Nick Morrice}

The Beatson Institute for Cancer Research, Glasgow, UK

This is a well written manuscript and provides an excellent reference for sample preparation ahead of any label free proteomics experiment. The protocols in the supplementary section are very detailed making them very easy for both novice and expert researchers to follow. The manuscript basically compares three different types of sample preparation and describes the positives and negative for each protocol if applied to label free quantification of proteins. This manuscript will be a very useful reference for anyone who wishes to perform label free quantification of proteins as the authors do highlight both the advantages and disadvantages of each approach.

The minor revisions I would like to see are in the description of creating a SWATH ion library using offline high pH RP-HPLC. The authors mention the addition of iRT peptides to each fraction, but do not describe why they are added. These retention time reference peptides are added so that any retention time drift from the ion library to the samples can be accounted for by the software used to analyse and quantify the SWATH data. I feel this should be described, especially for novices to the field. Secondly there is a slight complication in using the term eFASP in this manuscript. A very recent publication by Erde, J. et al. (2014) uses the term eFASP to describe a method that differs significantly from the one described here. I think this paper should be referred to in this manuscript just to highlight that the eFASP method used here was based on the method described by Shevchenko et al. (2012) and not to be confused with this more recent publication. Apart from these minor corrections, I have no reservations in approving this article.

Competing Interests: No competing interests were disclosed.

\section{I confirm that I have read this submission and believe that I have an appropriate level of expertise to confirm that it is of an acceptable scientific standard.}


Markus Ralser, University of Cambridge, Cambridge, UK

We thanks for these suggestions, and for spotting out the nomenclature overlap with Erde et al. (2014). As the Erde et al. article was published $\sim$ three months after the first version of this article we decided to keep the nomenclature, but add a caveat for clarification on two instances in the paper. An explanation/rationale about the use of retention time normalisation standards is now included as well.

Competing Interests: None

Reviewer Report 27 February 2014

https://doi.org/10.5256/f1000research.3109.r3900

(C) 2014 Lai X. This is an open access peer review report distributed under the terms of the Creative Commons Attribution License, which permits unrestricted use, distribution, and reproduction in any medium, provided the original work is properly cited.

\section{Xianyin Lai}

Department of Cellular and Integrative Physiology, Indiana University, Indianapolis, IN, USA

In their manuscript, Vowinckel et al. evaluated 6 sample preparation methods for label-free quantification, compared DDA and SWATH approaches of TripleTOF5600, and drew two major conclusions. The organization of the manuscript is clear, it is well-written, and the coverage is effective. The first conclusion is supported by their results. However, the second conclusion should be clarified that SWATH outperformed DDA in quantification when a TripleTOF5600 was applied. Without the clarification, it misleads scientists to believe that SWATH outperforms all DDA approaches carried out using other mass spectrometers. Figure $2 \mathrm{C}$ shows that DDA of QExactive detected about $40 \%$ more proteins than SWATH of TripleTOF5600. It is necessary to compare DDA of QExactive with SWATH of TripleTOF5600.

\section{Minor issues:}

"Protein Discoverer" should be "Proteome Discoverer"

Competing Interests: No competing interests were disclosed.

\section{I confirm that I have read this submission and believe that I have an appropriate level of expertise to confirm that it is of an acceptable scientific standard.}

Author Response ( ) 07 Apr 2014

Markus Ralser, University of Cambridge, Cambridge, UK

We thank the reviewer for the suggestion and clarify this now. Indeed, the TripleTOF5600 and Qexactive data can only to be compared indirectly/correlative in this study, but not 
absolutely, as different chromatography, HPLC, and ionisation settings were used. Therefore, the study can not be used to compare the Qexactive and TripleTOF instruments. However, in relative terms the protocols perform equally on both platforms, see Figure $2 d$, inset. As suggested, we have improved this part in manuscript and abstract, and included the Reviewer's comments.

Competing Interests: No competing interests were disclosed.

The benefits of publishing with F1000Research:

- Your article is published within days, with no editorial bias

- You can publish traditional articles, null/negative results, case reports, data notes and more

- The peer review process is transparent and collaborative

- Your article is indexed in PubMed after passing peer review

- Dedicated customer support at every stage

For pre-submission enquiries, contact research@f1000.com 